\title{
Desenvolvimento local sustentável e governança ambiental
}

\author{
Denise Kronemberger \\ Valéria Grace Costa
}

O desenvolvimento local foi impulsionado no Brasil em meados da década de 1990 e resultou de algumas mudanças importantes, como o processo de redemocratização nos anos 1980, com a descentralização do planejamento e gestão das políticas públicas e a ampliação da participação da sociedade na esfera pública.

Nos anos 1990 continua o processo de consolidação de um novo padrão de relação entre Estado e sociedade, baseado na participação social, na formação de parcerias, na busca de integração das ações, nas articulações inter e intragovernamentais. Verifica-se, desde então, a proliferação de iniciativas inovadoras governamentais, sobretudo de governos municipais e não governamentais, a ampliação das metodologias de apoio ao desenvolvimento local, e o surgimento de diversos arranjos institucionais, que se tornam espaços de interlocução, de governança, tais como: fóruns, agências, conselhos, comitês e consórcios.

Tal processo constitui, desde então, um elemento central para se conhecer a geografia do Brasil contemporâneo, uma vez que a ação pública sobre o território passa a refletir, de alguma forma e, crescentemente, a pressão política que os diversos segmentos da sociedade brasileira passam a exercer nas escalas local, regional e nacional.

Nesta primeira parte, apresentamos os conceitos mais importantes sobre desenvolvimento local e governança. Esta última diz respeito à dimensão político-institucional do desenvolvimento, que perpassa todas as demais dimensões. Na segunda parte contém uma breve análise da governança ambiental no Brasil, com ênfase nos municípios. A ênfase dada à governança ambiental é importante para introduzir o debate nas discussões acerca do desenvolvimento local e suscitar novos trabalhos e aprofundamentos. 
Procuramos selecionar variáveis que se identificam com a ideia de desenvolvimento local, como diferentes formas de articulação e de arranjos institucionais. Os dados foram obtidos em pesquisas do Instituto Brasileiro de Geografia e Estatística - IBGE sobre o número de organizações da sociedade civil que atuam na área de meio ambiente e proteção animal, os municípios que realizam articulações interinstitucionais na área de meio ambiente, municípios que firmam parcerias dos governos municipais com o governo federal para implementação de programas de meio ambiente e algumas institucionalidades participativas, entre outras instâncias e formas de praticar a governança ambiental no País. Sempre que possível foi apresentada série histórica em nível nacional e os mapas foram elaborados com base no último ano do dado disponível.

\section{Desenvolvimento local sustentável}

Desenvolvimento local é o processo de aproveitamento das vantagens comparativas e competitivas de uma localidade para favorecer o seu crescimento econômico, melhorar a qualidade de vida da população, fortalecer o capital social ${ }^{1}$, promover uma boa governança e o uso sustentável dos recursos naturais (PAULA, 2008). Nota-se que para um desenvolvimento local convergem fatores ambientais, sociais, econômicos, políticos e institucionais, que se cruzam e se interpenetram.

É um processo endógeno de mudanças estruturais, conduzido a partir dos atores locais ('desenvolvimento endógeno'), ou seja, realizado de 'baixo para cima'² (bottom up), através da sua mobilização e articulação em torno de um projeto coletivo, aproveitando as potencialidades e capacidades locais e as oportunidades do contexto externo, e minimizando as restrições ou fatores que o dificultam (BUARQUE, 2002). É, portanto, "uma nova estratégia de desenvolvimento, em que a comunidade assume um novo papel: de comunidade demandante, ela emerge como agente, protagonista, empreendedora, com autonomia e independência" (ALCOFORADO, 2006, p. 86).

Para alcançar estes objetivos é necessário que a sociedade local tenha capacidade de "formular propósitos coletivos, de progresso material, equidade, justiça social e sustentabilidade e mobilizar os recursos necessários para sua obtenção" (SENRA, 2010, p. 5), que é o conceito de Desenvolvimento Econômico Territorial - DET, segundo a formulação do Instituto Latinoamericano y del Caribe de Planificación Econômica y Social - ILPES da Comisión Econômica para América latina y el Caribe - Cepal (SENRA, 2010, p. 5). O diferencial do desenvolvimento local em relação a outros paradigmas de desenvolvimento está na incorporação da dimensão territorial, pois é uma construção de atores mobilizados em um processo dinâmico de valorização de ativos locais na base de uma identificação coletiva com uma

\footnotetext{
1 Capital social é a "capacidade de uma sociedade de estabelecer laços de confiança interpessoal e redes de cooperação com vistas à produção de bens coletivos" (ARAÚJO, 2003, p. 10).

2 Não se quer dizer com isto que o desenvolvimento será buscado somente de baixo para cima, pois a participação cidadã não prescinde do papel fundamental do Estado.
} 
cultura e um território. Estes ativos são os recursos próprios de um território, que permitirão a este se diferenciar em relação aos demais territórios (PECQUEUR, 2005).

Desse modo, o desenvolvimento local é focado nas pessoas, no seu ambiente e na sua capacidade para inovar, efetuar transformações e empreender, baseado em valores como cooperação, solidariedade, partilha, complementaridade, confiança, corresponsabilidade. Tem como referência a formação de parcerias, as articulações em rede e os ativos locais (potenciais individuais e coletivos, oportunidades, vantagens comparativas e competitivas) (MELO NETO; FRÓES, 2002).

O desenvolvimento local pode ocorrer em diversos recortes territoriais, porque o local é produto do processo de desenvolvimento, da participação social, sendo um espaço que vai sendo construído pela sociedade, que vai originando configurações territoriais diversas. É o alvo socioterritorial das ações, portanto, não é dado, mas se define e redefine a partir destas ações, o que remete a um contexto de relações que ultrapassa o nível micro. Por isso, ele também é denominado desenvolvimento territorial (FRANCO, 1998, 2002; SPERANZA, 2006; SILVEIRA, 2010). Portanto, o local não é uma questão de escala, também "não se trata do mesmo desenvolvimento em miniatura", mas é uma questão de natureza, é um "outro desenvolvimento", conforme aponta Silveira (2010, p. 46). Local também tem relação com identidade, que pode ser construída politicamente, tem a ver com o sentido de pertencimento, com a conexão e um sentido compartilhado de uma história vivida de maneira conjunta (TENÓRIO, 2012).

Qual, então, é a relação entre desenvolvimento local e governança?

Governança é o conjunto das várias maneiras pelas quais os diversos atores sociais se articulam e cooperam, realizando ações, gerenciando seus problemas comuns e acomodando seus interesses. Abrange instituições públicas e privadas, regimes formais de coordenação e autoridade, como os aspectos gerenciais do Estado, mecanismos informais que atendam a determinadas necessidades e redes sociais informais (MILANI; SOLINÍS, 2002, apud ALBAGLI, 2007).

Implica, por exemplo, na formação de parcerias, constituição de arranjos institucionais com a participação conjunta de governos-empresas-sociedade, entre outras formas de articulação. Uma boa governança é, portanto, fundamental no processo de desenvolvimento local sustentável.

Particularmente a governança ambiental exerce um papel fundamental na viabilização de um uso sustentável dos recursos naturais, um dos principais objetivos do desenvolvimento local, porque estimula a inserção dos movimentos sociais e ambientais nos processos decisórios e a ação política com autonomia e independência, favorecendo o real exercício da cidadania e da democracia em busca do bem-estar. Refere-se a "que, na área do meio ambiente, estejam ampliando os espaços de participação dos diversos segmentos da sociedade civil organizada" (OLIVEIRA; BARCELLOS; GREEN, 2011, p. 17).

No Brasil, ocorre uma multiplicidade de ações públicas e privadas que visam apoiar ou induzir o desenvolvimento local, como a Agenda 21 Local, os Programas de Desenvol- 
vimento Regional, os empreendimentos de Economia Solidária ${ }^{3}$, os Arranjos Produtivos Locais - APL, iniciativas de empreendedorismo social ${ }^{4}$, tecnologias sociais ${ }^{5}$, inclusão digital e muitas outras. Essa diversidade de ações constitui, de certa forma, tentativas de implementar uma nova dinâmica territorial do desenvolvimento. Elas têm etapas de execução diferentes, porém, têm em comum a formação de redes sociais e o fomento às dinâmicas democrático-participativas. Visam tornar as comunidades protagonistas do seu desenvolvimento, ao participarem das tomadas de decisão.

Estas iniciativas compõem um processo onde emergem novos atores, que criam novas territorialidades, uma vez que alteram as suas relações com as localidades/regiões, ou seja, mudam o modo de agir em seu meio de referência, podendo, inclusive, contribuir para criar laços mais fortes de identidade territorial (sentido de pertencimento), quando expressam resistência aos mecanismos da globalização ou quando aproveitam as potencialidades para valorizar os territórios (ALBAGLI, 2004). As experiências da Associação de Desenvolvimento Sustentável e Solidário da Região Sisaleira - АРАEB, na Bahia, da Associação dos Agricultores Ecológicos das Encostas da Serra Geral - Agreco, em Santa Catarina, e as regiões com o registro de Indicação Geográfica - IG são alguns exemplos destas iniciativas.

Quando surgiu em 1980 no Município de Valente, na Bahia, a APAeB tinha como principal objetivo valorizar a produção de sisal. Posteriormente, a iniciativa foi se ampliando, incorporando municípios vizinhos e contemplando outros temas, como a convivência com a seca, a educação, a comunicação, a cultura, o crédito, o meio ambiente e o desenvolvimento sustentável.

A AGRECO, no seu início, em 1996, visava produzir hortifrutigranjeiros com manejo ecológico, no Município de Santa Rosa de Lima, em Santa Catarina. A iniciativa ampliou-se, estendendo-se pela Região das Encostas da Serra Geral e incorporando outras atividades, como as agroindústrias organizadas de forma associativa (Rede AGRECO), projetos de ecovilas, comércio solidário, agroturismo, cooperativa de crédito, agricultura ecológica, e inserção dos agricultores de pequeno e médio porte em nichos de mercados nacionais e internacionais, através de produtos artesanais e orgânicos.

\footnotetext{
3 Para Singer (2003, p. 11-28): “A economia solidária surge como modo de produção e distribuição alternativo ao capitalismo [...]. Casa o princípio da unidade entre posse e uso dos meios de produção e distribuição [...] com o princípio da socialização destes meios". Como exemplos estão as cooperativas populares, as empresas de autogestão, os clubes de troca e os projetos de economia de comunhão, entre outros.

4 O empreendedorismo social produz bens e serviços para solucionar problemas sociais, não está voltado para os mercados, mas para atender as pessoas em situação de exclusão social, pobreza e risco de vida. Seu objetivo é capacitar para ações empreendedoras, para "empoderar" as comunidades (MELO NETO; FRÓES, 2002). Como exemplos podem ser mencionadas as ações da Pastoral da Criança, organismo de ação social da Confederação Nacional dos Bispos do Brasil - CNBB e do Comitê de Democratização da Informática - CDI, organização social que usa a tecnologia para transformação social, como as Escolas de Informática e Cidadania, entre outras.

5 Para Melo Neto e Fróes (2002, p. 34): "Arranjos institucionais definidos e implementados por associações, pelos governos em seus diversos níveis, universidades, sindicatos, equipes gestoras dos programas e projetos de desenvolvimento social em uma comunidade e pelos membros da comunidade".
} 
As IGs decorrem da valorização de ativos locais, produtos tradicionais com qualidade diferenciada, vinculados a determinados territórios, reconhecidos pelo Instituto Nacional de Propriedade Intelectual - INPI. Procuram contribuir para a conservação ambiental, para a economia local e para o dinamismo regional. São exemplos: em Goiabeiras Velha, bairro antigo na parte continental norte de Vitória, as panelas de barro; no Pampa gaúcho, da Campanha Meridional, a carne bovina e seus derivados; também no Rio Grande do Sul, no Município de Pelotas - os doces tradicionais de confeitaria e de frutas e no Vale dos Vinhedos - os vinhos e espumantes; em Paraty, no Estado do Rio de Janeiro, as aguardentes; na Região do Cerrado mineiro, o café; na Região do Jalapão, do Estado do Tocantins, o artesanato em capim dourado, entre outros (INDICAÇÕES..., 2014).

Em todos estes exemplos a dimensão ambiental do desenvolvimento local está presente, considerando que as condições ambientais exercem influência nas características dos produtos, como também a necessidade de conservar as regiões produtoras, garantindo sua sustentabilidade.

\section{Governança ambiental no Brasil}

\section{Organizações da sociedade civil}

As organizações da sociedade civil representam a capacidade de intervenção ativa das comunidades na realidade em que vivem. Contribuem para aumentar a capacidade da sociedade de exercer a sua cidadania e desenvolver-se de forma sustentável.

Em 2010, existiam no Brasil um total de 2242 Fundações Privadas e Associações sem Fins Lucrativos - FASFIL que desenvolviam ações de meio ambiente e proteção animal, representando apenas $0,8 \%$ do total das FAsfil do País. Vale ressaltar, contudo, que como o tema é transversal, meio ambiente também pode ser tratado por entidades com outras finalidades. A maioria das FASFIL (60,0\%) foi fundada entre 2001 e 2010. Em termos de pessoal ocupado assalariado, elas empregavam 10337 trabalhadores, representando 0,5\% do total de pessoal ocupado nas FASFIL. A maioria encontrava-se nas Regiões Sudeste (3 972) e Nordeste (3 963) (AS FUNDAÇÕES..., 2012). 
A maioria das FASFIL de meio ambiente localizava-se nas Regiões Sudeste (50,0\%) e Sul (23,0\%). Os Estados de São Paulo, Minas Gerais e Rio de Janeiro possuíam o maior número de unidades (574, 285 e 213, respectivamente) (Mapa 1). Por outro lado, quando analisadas segundo o tamanho de população das Unidades da Federação, Santa Catarina, Distrito Federal e Rio Grande do Sul possuíam o maior número de FASFIL por mil habitantes, conforme apresentado no Gráfico 1.

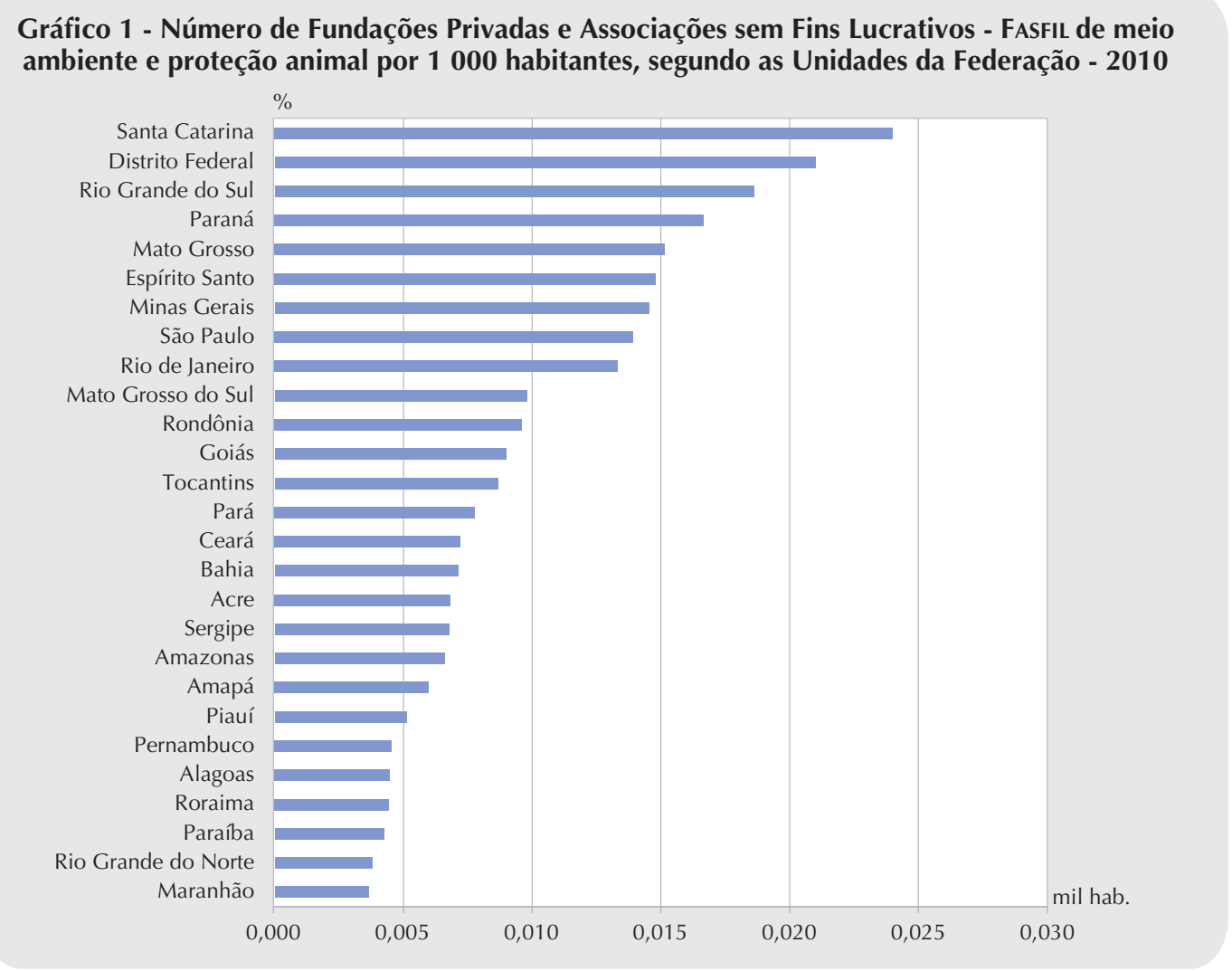

Fonte: As fundações privadas e associações sem fins lucrativos no Brasil 2010. Rio de Janeiro: IBGE, 2012. (Estudos e pesquisas. Informação econômica, n. 20). Estudo realizado pelo IBGE em parceria com o Instituto de Pesquisa Econômica Aplicada - IPEA, a Associação Brasileira de Organizações Não Governamentais - Abong e o Grupo de Institutos, Fundações e Empresas - GIFE. Disponível em: <ftp://ftp.ibge.gov.br/Fundacoes_Privadas_e_Associacoes/2010/fasfil.pdf>. Acesso em: maio 2016.

Entre os municípios, 42,0\% possuíam apenas uma FASFIL e 25,0\% tinham somente duas. Os dez municípios com os maiores números de unidades locais, em 2010, eram: São Paulo (162), Rio de Janeiro (95), Curitiba (64), Brasília (54), Porto Alegre (40), Belo Horizonte (34), Fortaleza (24), Salvador (24), Belém (23) e Campinas (23) (Mapa 1). 
Mapa 1 - Fundações Privadas e Associações sem Fins Lucrativos - Fasfil de meio ambiente e proteção animal nos municípios brasileiros com pelo menos 50000 habitantes - 2010

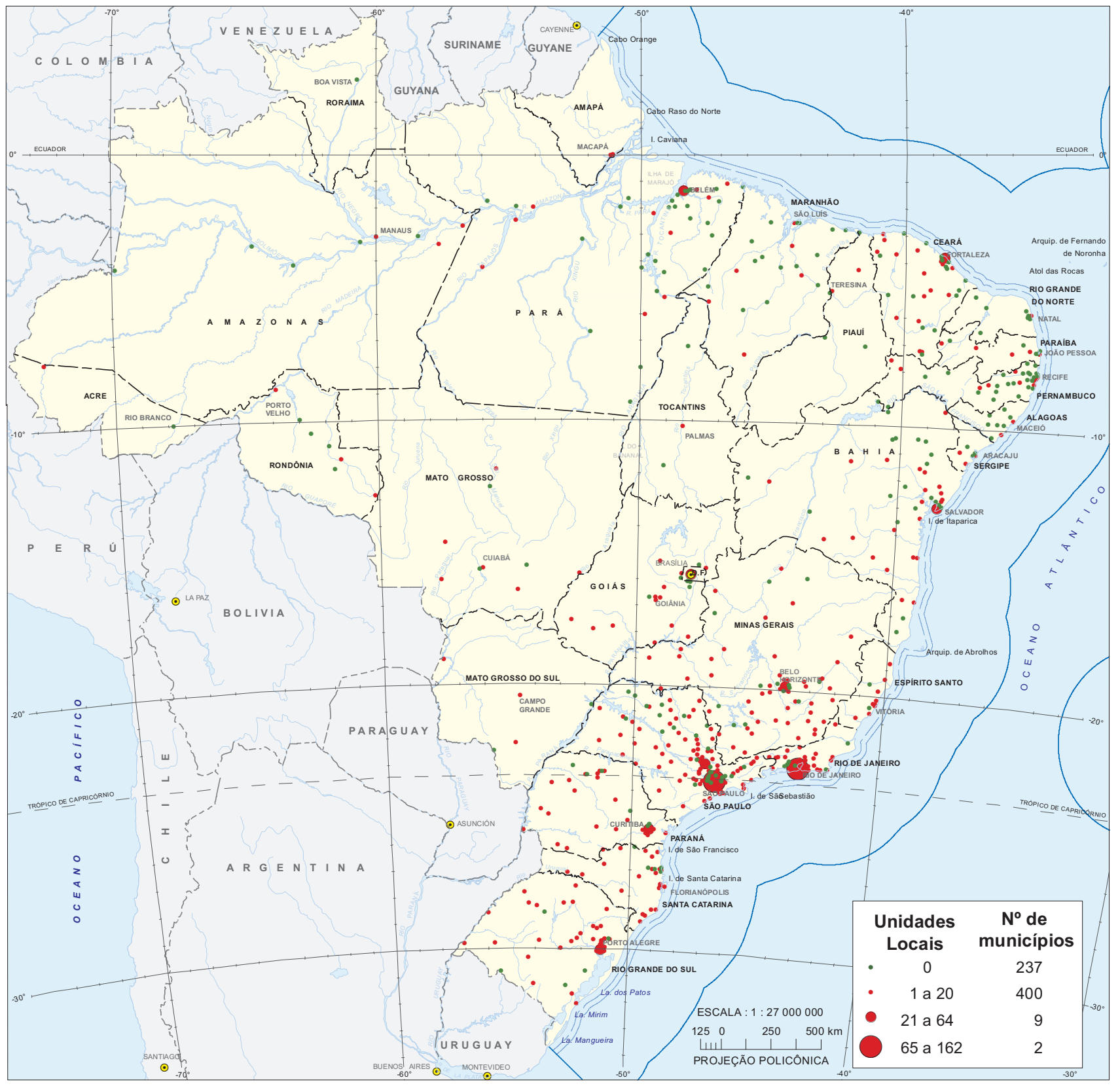

Fonte: As fundações privadas e associações sem fins lucrativos no Brasil 2010. Rio de Janeiro: IBGE, 2012. (Estudos e pesquisas. Informação econômica n. 20). Estudo realizado pelo IBGE em parceria com o Instituto de Pesquisa Econômica Aplicada - IPEA, a Associação Brasileira de Organizações Não Governamentais - ABONG e o Grupo de Institutos, Fundações e Empresas - GIFE. Disponível em: <ftp://ftp.ibge.gov.br/Fundacoes_Privadas_e_ Associacoes/2010/fasfil.pdf>. Acesso em: maio 2016. 


\section{Institucionalidades participativas}

No processo de desenvolvimento local também são criadas 'novas institucionalidades', que são instâncias de governança, para apoiar esse processo ou parte dele. São os Fóruns, as Agências, os Comitês de Bacias Hidrográficas, os Conselhos Municipais, os Conselhos de Desenvolvimento, os Consórcios Intermunicipais, as Associações de Municípios e as Redes, que conferem maior representatividade política e social ao desenvolvimento local. Eles constituem espaços públicos de negociação e participação cidadã.

Nesse trabalho será analisada a distribuição espacial dos municípios com Conselhos de Meio Ambiente, com participação em Comitês de Bacias Hidrográficas - CBH e com Fóruns da Agenda 21 Local. Os CBH, por exemplo, são arranjos institucionais participativos que apoiam o desenvolvimento local, na medida em que procuram a interação entre os atores sociais (representantes do poder público, da sociedade civil e dos usuários da água) para ordenar a ocupação das bacias, buscando o uso criterioso da água, criando, utilizando e fortalecendo as instituições locais.

\section{Conselhos de Meio Ambiente}

Os Conselhos Municipais de Meio Ambiente são órgãos colegiados inseridos no poder executivo municipal, de natureza deliberativa ou consultiva, integrados por diferentes atores sociais (governo, empresariado, universidades, trabalhadores e sociedade civil) que lidam com temas relacionados com o meio ambiente e que integram a estrutura dos órgãos locais do Sistema Nacional do Meio Ambiente - Sisnama. Tais Conselhos têm como função acompanhar a implementação da política ambiental do município, negociar demandas e interesses e mediar conflitos (LEDO, 2013).

Embora não esteja prevista de forma direta nem obrigatória a criação de Conselhos pelos municípios na Constituição Federal do Brasil de 1988, ao contrário de outros instrumentos como o plano diretor, alguns preceitos constitucionais indicam a gestão participativa nas diversas esferas de poder. Além disso, o texto constitucional ressalta a importância do município para o desenvolvimento local sustentável. Tais pressupostos são respaldados pelo princípio de descentralização e da gestão democrática, claramente explícitos na Constituição do Brasil de 1988.

A criação e a implementação dos Conselhos de Meio Ambiente vão ao encontro do estabelecido no Art. 225 da Constituição do Brasil de 1988 que enuncia como "direito comum a todos o usufruto de um meio ambiente ecologicamente equilibrado, considerado bem de uso comum e essencial à sadia qualidade de vida" (BRASIL, 2016a). De forma mais direta a relação e a função dos Conselhos podem ser identificadas na continuidade do mesmo texto ao enunciar que "compete ao poder público e à coletividade o dever de defendê-lo e de preservá-lo para as gerações atuais e futuras" (BRASIL, 2016a).

A Resolução n. 237, de 19.12.1997, do Conselho Nacional do Meio Ambiente - ConamA fundamenta juridicamente, de forma mais específica, a criação e a importância dos Conselhos de Meio Ambiente através do seu Art. 20 ao tratar das competências licenciatórias dos entes federados: "Os entes federados, para exercerem suas competências licenciatórias, deverão 
ter implementados os Conselhos de Meio Ambiente, com caráter deliberativo e participação social e, ainda, possuir em seus quadros ou a sua disposição profissionais legalmente habilitados (CONSELHO NACIONAL DO MEIO AMBIENTE, 2003).

Em nível federal o Conama atende esta função. Em nível estadual há os Conselhos Estaduais de Meio Ambiente e, em nível local, os Conselhos Municipais de Meio Ambiente. Embora existam algumas recomendações estabelecidas pelo Conama e pelo Instituto Brasileiro do Meio Ambiente e dos Recursos Naturais Renováveis - IBAma em relação às atribuições dos Conselhos, os municípios possuem autonomia para a elaboração do projeto de lei de criação, bem como para o estabelecimento de sua competência e funções. Entretanto, a composição da representação dos diversos segmentos sociais, bem como a indicação nominal dos seus membros, é estabelecida pela prefeitura.

De acordo com a Resolução n. 237, de 19.12.1997, do Conama, entre as principais funções geralmente atribuídas aos conselhos municipais é possível destacar as relacionadas a seguir:

- propor a política ambiental do município e fiscalizar o seu cumprimento;

- promover a educação ambiental;

- propor a criação de normas legais, bem como a adequação e regulamentação de leis, padrões e normas municipais, estaduais e federais;

- opinar sobre aspectos ambientais de políticas estaduais ou federais que tenham impactos sobre o município; e

- receber e apurar denúncias feitas pela população sobre degradação ambiental, sugerindo à prefeitura as providências cabíveis (CONSELHO NACIONAL DO MEIO AMBIENTE, 2003) .

O IвAma sugere que o Conselho Municipal de Meio Ambiente tenha uma composição paritária, ou seja, que considere, em igualdade numérica, representantes do poder público e da sociedade civil organizada. Essa composição pode ser bipartite - poder público (municipal, estadual e federal) e outros segmentos (empresarial, sindical, academia, entidades ambientalistas etc.) - ou tripartite - poder público, setor produtivo (empresarial e sindical) e entidades.

A prefeitura deve fornecer todas as condições para o funcionamento do Conselho Municipal de Meio Ambiente. Por isso, convém que antes da sua criação seja instalado o órgão ambiental municipal. Este órgão deverá ter capacidade técnica suficiente para dar apoio, inclusive administrativo, ao funcionamento do Conselho. Cabe ainda ao executivo municipal colocar em prática as decisões do Conselho para que este se torne um efetivo instrumento de promoção de qualidade ambiental no município (CONSELHO NACIONAL DO MEIO AMBIENTE, 2003).

Além da representatividade de diversos segmentos sociais, a importância e o nível de atuação dos conselhos também podem ser avaliados de acordo com sua atividade efetiva. Desta maneira, a frequência com que realizam as reuniões, embora não revele a qualidade da atuação, nos permite diferenciá-los de alguma forma. A Pesquisa de Informações Básicas Municipais - MUNIC, do IBGE levantou esta informação. 
Foram considerados ativos, os conselhos que realizaram reunião pelo menos uma vez nos 12 meses anteriores à data de referência da pesquisa. A existência de um Conselho ativo pode indicar que há alguma forma de participação comunitária na gestão municipal.

Em 2013, 3784 municípios possuíam Conselhos de Meio Ambiente, dentre os quais 2873 eram ativos, representando $74,7 \%$ daqueles que possuíam Conselhos de Meio Ambiente e 50,7\% do total de municípios brasileiros. Considerando que em 2001, havia 22,3\% municípios brasileiros com Conselhos ativos, houve um aumento considerável nesta forma de participação, superior a 100\% no Brasil como um todo.

A distribuição desses Conselhos por Grandes Regiões também mostra estas diferenças, conforme apresentado no Gráfico 2. Com exceção do Nordeste, que apresenta um número relativamente menor do número de municípios com Conselhos, o comportamento das outras regiões é bem semelhante entre si e com o do Brasil.

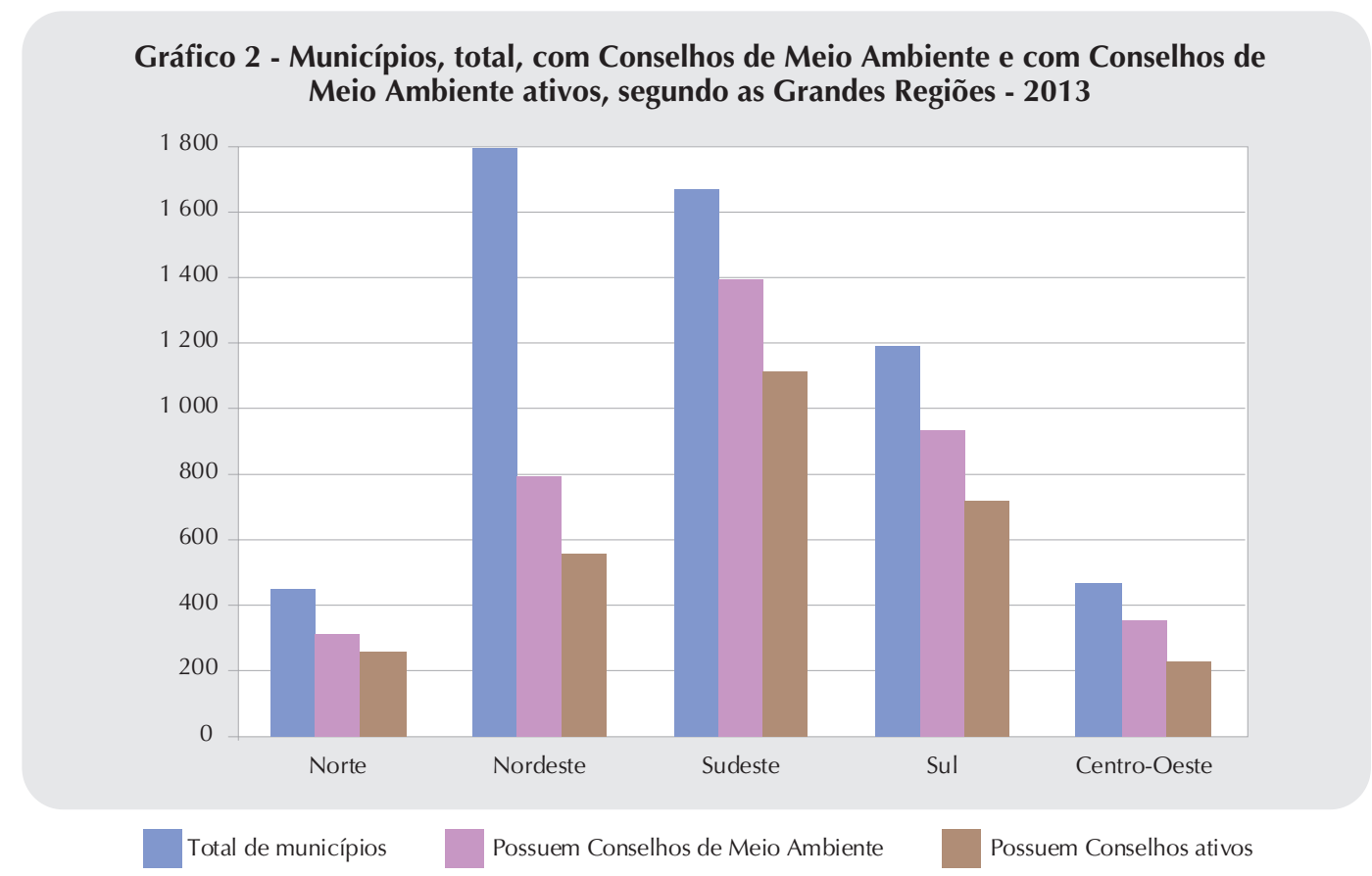

Fonte: IBGE, Pesquisa de Informações Básicas Municipais 2013.

A quantidade de reuniões anuais, no entanto, varia bastante no total de municípios, desde aqueles que fizeram somente uma reunião durante o ano (381 municípios) até aquele que realizou 60 encontros (um município), conforme o Mapa 2. A média de reuniões foi em torno de seis por ano. 
As maiores frequências ocorreram nos 437 municípios que realizaram duas ou nos 402 municípios com 12 reuniões anuais. O Mapa 2 também revela que a região com maior número de municípios com Conselhos de Meio Ambiente ativos foi a Sudeste, seguida da Região Sul. Os valores percentuais também são maiores nestas duas regiões (Tabela 3). De todos os estados, Minas Gerais é o mais representado em relação ao número de Conselhos Municipais de Meio Ambiente, com 521 municípios. No entanto, se considerarmos os valores relativos, Rio de Janeiro e Rio Grande do Sul possuem posição de destaque no que se refere à atividade dos Conselhos (Tabelas 2 e 3 ).

Quando o enfoque é relacionado com o tamanho populacional dos municípios, fica evidenciada a maior participação, em termos absolutos, dos municípios menores, de até 50000 habitantes, tanto no Brasil como em cada uma das Grandes Regiões. Em termos relativos, no entanto, há uma crescente representação nas faixas de população, variando de 41,0\% (municípios com até 5000 habitantes) a 92,0\% (municípios com população superior a 500000 habitantes), conforme apresentado na Tabela 1.

Tabela 1- Municípios, total e com Conselhos Municipais de Meio Ambiente ativos, segundo as classes de tamanho da população dos municípios - Brasil - 2013

\begin{tabular}{|c|c|c|c|c|}
\hline \multirow{3}{*}{$\begin{array}{l}\text { Classes de tamanho da } \\
\text { população dos municípios }\end{array}$} & \multicolumn{4}{|c|}{ Municípios } \\
\hline & \multirow{2}{*}{\multicolumn{2}{|c|}{ Total }} & \multicolumn{2}{|c|}{ Com Conselhos de Meio Ambiente ativos } \\
\hline & & & Total & Percentual (\%) \\
\hline Brasil & & 5570 & & 51,58 \\
\hline Até 5000 hab. & & 1247 & & 41,46 \\
\hline De 5001 a 10000 hab. & & 1227 & & 42,54 \\
\hline De 10001 a 20000 hab. & & 1378 & & 46,37 \\
\hline De 20001 a 50000 hab. & & 1080 & & 61,57 \\
\hline De 50001 a 100000 hab. & & 339 & & 77,88 \\
\hline De 100001 a 500000 hab. & & 260 & & 88,46 \\
\hline Mais de 500000 hab. & & 39 & & 92,31 \\
\hline
\end{tabular}

Fonte: IBGE, Pesquisa de Informações Básicas Municipais 2013.

A Tabela 2 mostra que nas Regiões Norte e Nordeste houve o predomínio de Conselhos ativos nos municípios situados na faixa entre 10000 e 50000 habitantes, enquanto no Sudeste todos os estratos inferiores a 50000 habitantes foram bem representados. No Sul, houve destaque para o estrato das menores cidades em tamanho populacional: até 5000 habitantes. A Região Centro-Oeste é a que possui menor número de municípios com Conselhos de Meio Ambiente ativos com a participação predominante nos quatro primeiros estratos populacionais. 
Tabela 2 - Municípios com Conselhos de Meio Ambiente e com Conselhos de Meio Ambiente por Grandes Regiões, segundo as classes de tamanho da população dos municípios - 2013

\begin{tabular}{|c|c|c|c|c|c|c|c|c|c|c|}
\hline \multirow{3}{*}{$\begin{array}{c}\text { Classes de tamanho da } \\
\text { população dos municípios }\end{array}$} & \multicolumn{10}{|c|}{ Municípios com Conselhos de Meio Ambiente } \\
\hline & \multicolumn{2}{|c|}{ Norte } & \multicolumn{2}{|c|}{ Nordeste } & \multicolumn{2}{|c|}{ Sudeste } & \multicolumn{2}{|c|}{ Sul } & \multicolumn{2}{|c|}{ Centro-Oeste } \\
\hline & Total & Ativos & Total & Ativos & Total & Ativos & Total & Ativos & Total & Ativos \\
\hline Total & 450 & 258 & 1794 & 558 & 1668 & 1113 & 1191 & 717 & 467 & 227 \\
\hline Até 5000 hab. & 80 & 31 & 234 & 17 & 374 & 208 & 420 & 215 & 139 & 46 \\
\hline De 5001 a 10000 hab. & 81 & 36 & 360 & 58 & 397 & 228 & 280 & 149 & 109 & 51 \\
\hline De 10001 a 20000 hab. & 110 & 66 & 577 & 163 & 359 & 230 & 228 & 132 & 104 & 48 \\
\hline De 20001 a 50000 hab. & 111 & 68 & 443 & 197 & 290 & 226 & 159 & 122 & 77 & 52 \\
\hline De 50001 a 100000 hab. & 42 & 34 & 119 & 73 & 107 & 92 & 52 & 51 & 19 & 14 \\
\hline De 100001 a 500000 hab. & 24 & 21 & 50 & 40 & 124 & 113 & 48 & 44 & 14 & 12 \\
\hline Mais de 500000 hab. & 2 & 2 & 11 & 10 & 17 & 16 & 4 & 4 & 5 & 4 \\
\hline
\end{tabular}

Fonte: IBGE, Pesquisa de Informações Básicas Municipais 2013.

Em termos percentuais, os valores acompanham, em nível nacional, uma crescente variação, conforme o aumento do tamanho populacional dos municípios (Tabela 3).

Tabela 3 - Percentual de municípios com Conselhos de Meio Ambiente ativos em relação ao total de municípios com Conselhos de Meio Ambiente, por Grandes Regiões, segundo as classes de tamanho da população dos municípios - 2013

\begin{tabular}{|c|c|c|c|c|c|}
\hline \multirow{2}{*}{$\begin{array}{c}\text { Classes de tamanho da } \\
\text { população dos municípios }\end{array}$} & \multicolumn{5}{|c|}{ Percentual de municípios com Conselhos de Meio Ambiente ativos (\%) } \\
\hline & Norte & Nordeste & Sudeste & Sul & Centro-Oeste \\
\hline Total & 57,3 & 31,1 & 66,7 & 60,2 & 48,6 \\
\hline Até 5000 hab. & 38,8 & 7,3 & 55,6 & 51,2 & 33,1 \\
\hline De 5001 a 10000 hab. & 44,4 & 16,1 & 57,4 & 53,2 & 46,8 \\
\hline De 10001 a 20000 hab. & 60,0 & 28,2 & 64,1 & 57,9 & 46,2 \\
\hline De 20001 a 50000 hab. & 61,3 & 44,5 & 77,9 & 76,7 & 67,5 \\
\hline De 50001 a 100000 hab. & 81,0 & 61,3 & 86,0 & 98,1 & 73,7 \\
\hline De 100001 a 500000 hab. & 87,5 & 80,0 & 91,1 & 91,7 & 85,7 \\
\hline Mais de 500000 hab. & 100,0 & 90,9 & 94,1 & 100,0 & 80,0 \\
\hline
\end{tabular}

Fonte: IBGE, Pesquisa de Informações Básicas Municipais 2013.

A atuação dos Conselhos Municipais de Meio Ambiente pode contribuir para a melhoria da qualidade de vida da população municipal, visto suas atribuições de "definir, acompanhar, fiscalizar, promover e avaliar políticas, ações, projetos e programas referentes às questões relativas ao meio ambiente" (RIO DE JANEIRO, 2010, p. 62) dentre as quais os focos mais visíveis são os serviços relacionados com o saneamento ambiental (abastecimento de água, coleta e destinação do lixo, coleta e destinação dos esgotos sanitários e a drenagem pluvial). 
Mapa 2 - Municípios com Conselho de Meio Ambiente ativo - 2013

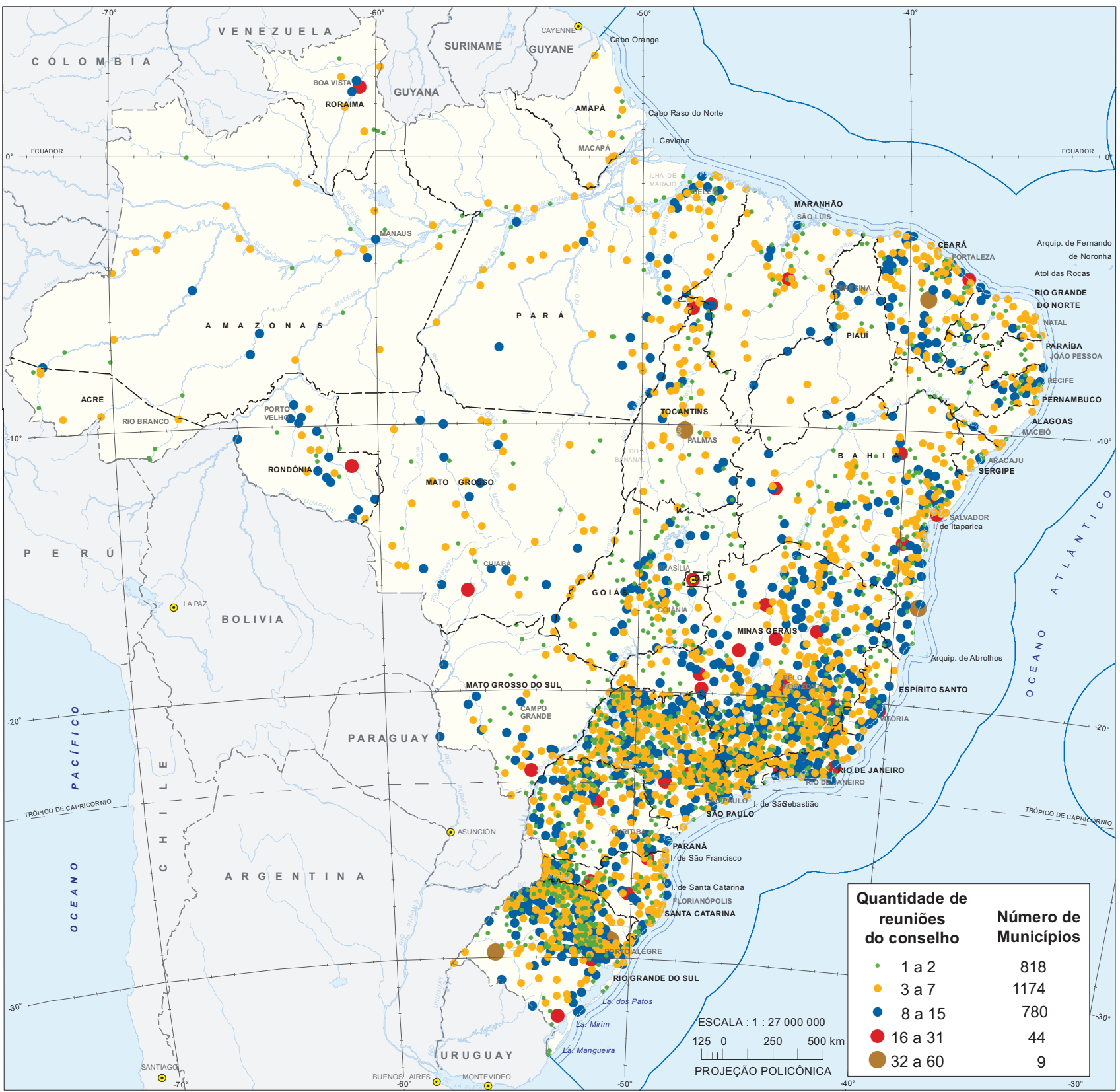

Fonte: IBGE, Pesquisa de Informações Básicas Municipais 2013. 


\section{Comitês de Bacias Hidrográficas}

Os Comitês de Bacias Hidrográficas - CBH integram o Sistema Nacional de Gerenciamento de Recursos Hídricos - SINGREH, criado pela Lei n. 9.433, de 08.12.1997, que estabelece a Política Nacional de Recursos Hídricos. Segundo essa Política, os comitês têm como competência: promover o debate entre as entidades intervenientes; articular sua atuação; arbitrar conflitos referentes ao uso da água; e aprovar o Plano de Recursos Hídricos, entre outras atribuições. Os comitês são arranjos institucionais compostos por representantes das esferas de governo federal, estadual e municipal, da sociedade civil, do setor privado e dos usuários das águas.

Com efeito, eles representam uma das formas de articulação intermunicipal ou entre a União e os Estados. Trata-se, portanto, de um modelo de gestão descentralizado e participativo para a tomada de decisões relativas ao uso, à recuperação e à conservação dos recursos hídricos. Os recursos hídricos podem contribuir para a segurança alimentar e nutricional, a saúde pública, a geração de hidroenergia, entre outros objetivos de desenvolvimento sustentável. Sua gestão, integrada e efetiva deve, portanto, considerar os aspectos ambientais, econômicos, sociais e político-institucionais das bacias hidrográficas.

De acordo com a MUNIC, do IBGE, em 2013, 73,1\% do total de municípios brasileiros participavam de CBH, enquanto em 2002 representavam 46,8\% (PERFIL..., 2014).

A distribuição destes municípios por classes de tamanho populacional, apresentada na Tabela 4, deixa evidenciada uma relevante participação em todos os estratos populacionais, considerando que tais valores relativos são superiores a 65,0\% de participação em cada um destes estratos. Observamos também que há a mesma tendência em relação aos Conselhos de Meio Ambiente, caracterizada pela participação crescente, conforme o tamanho dos municípios, chegando à quase totalidade nos municípios com população superior a 500000 habitantes.

Tabela 4 - Municípios, total e que participam de Comitê de Bacia Hidrográfica segundo as classes de tamanho da população dos municípios - Brasil - 2013

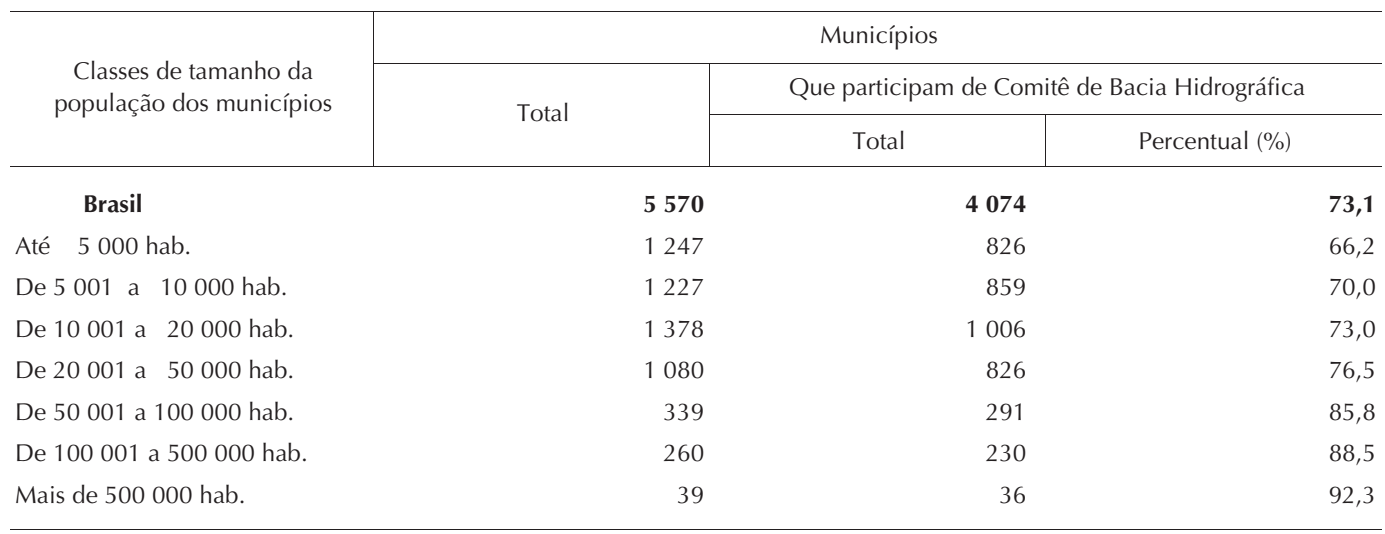

Fonte: IBGE, Pesquisa de Informações Básicas Municipais 2013. 
No recorte das Grandes Regiões, o Norte é a única que se diferencia quanto à tendência apresentada no Brasil de participação crescente conforme o tamanho da população, como apresentado na Tabela 5. Nesta região, ao contrário das demais, as cidades de até 5000 habitantes possuem maior representação em $\mathrm{CBH}$.

A distribuição segundo as Grandes Regiões (Tabela 5) mostra que a Região Sudeste possui a maior participação de municípios com $\mathrm{CBH}(93,2 \%)$ e do percentual correspondente às cidades com população acima de 500000 habitantes (94,1\%). A Região Sul também tem uma representação considerável, acompanhando o comportamento de primazia destas duas regiões em relação às institucionalidades participativas consideradas neste artigo. Por outro lado, a Região Norte é a que possui o menor número de municípios e a menor participação deles em CBH (34,9\%). Nesta região, Rondônia (32,7\%) possui maior percentual de participação municipal em Comitês, embora este ainda seja baixo se considerarmos a maioria dos estados do País.

Tabela 5 - Percentual de municípios com participação em Comitês de Bacias Hidrográficas, por Grandes Regiões, segundo as classes de tamanho da população dos municípios - 2013

\begin{tabular}{|c|c|c|c|c|c|}
\hline \multirow{2}{*}{$\begin{array}{l}\text { Classes de tamanho da } \\
\text { população dos municípios }\end{array}$} & \multicolumn{5}{|c|}{ Percentual de municípios com participação em Comitês de Bacias Hidrográficas (\%) } \\
\hline & Norte & Nordeste & Sudeste & Sul & Centro-Oeste \\
\hline Total & 34,9 & 65,2 & 93,2 & 77,1 & 58,7 \\
\hline Até 5000 hab. & 56,3 & 47,4 & 86,9 & 66,0 & 48,9 \\
\hline De 5001 a 10000 hab. & 33,3 & 52,5 & 91,9 & 75,7 & 60,6 \\
\hline De 10001 a 20000 hab. & 35,5 & 65,3 & 93,6 & 84,6 & 58,7 \\
\hline De 20001 a 50000 hab. & 16,2 & 76,5 & 97,9 & 85,5 & 63,6 \\
\hline De 50001 a 100000 hab. & 38,1 & 88,2 & 99,1 & 94,2 & 78,9 \\
\hline De 100001 a 500000 hab. & 41,7 & 80,0 & 99,2 & 97,9 & 71,4 \\
\hline Mais de 500000 hab. & 100,0 & 81,8 & 94,1 & 100,0 & 100,0 \\
\hline
\end{tabular}

Fonte: IBGE, Pesquisa de Informações Básicas Municipais 2013.

No Nordeste, Ceará $(94,6 \%)$ e Pernambuco $(77,3 \%)$ se destacam com valores acima do valor médio da região $(65,2 \%)$ e do Brasil $(73,0 \%)$. O estado menos representado nesta região é o Maranhão, com apenas 27,0 \% de municípios com participação em CBH.

Na Região Sul há uma representação bem equilibrada entre os três estados que a compõe, com um pequeno predomínio de Santa Catarina $(84,7)$, enquanto no Centro-Oeste destaca-se o Estado de Mato Grosso do Sul (86,0\%).

Os extremos são representados pelo Estado do Amapá, que não possui municípios com participação em CBH, e o Estado de São Paulo, no qual apenas um de seus 645 municípios não faz parte desse tipo de organismo (PERFIL..., 2014). 
Através da representação no Mapa 3 é possível visualizarmos o comportamento apresentado anteriormente, relativo à distribuição da participação municipal nas Unidades da Federação do País e nas regiões hidrográficas.

As regiões hidrográficas correspondem à divisão que considera as grandes bacias hidrográficas do País, definidas segundo o Conselho Nacional de Recursos Hídricos - CNRH. De acordo com a Resolução n. 32, de 15.10.2003, do CNRH, o Brasil passou a ser dividido em 12 regiões hidrográficas, conforme apresentadas no Mapa 3.

As regiões hidrográficas, cujos municípios possuem maior participação em CBH são aquelas nas quais as suas áreas territoriais estão predominantemente nas Regiões Sul e Sudeste do País, reforçando o padrão apresentado anteriormente quando analisamos a distribuição por Unidades da Federação. O Mapa 3 e a Tabela 6 evidenciam a maior representação espacial e participação das Bacias do Atlântico Sudeste, do Rio Paraná, Rio São Francisco e Rio Uruguai.

Destaca-se, neste sentido, a Bacia do Atlântico Sudeste que contém as Bacias do Rio Paraíba do Sul e do Rio Doce. Nessas bacias, distinguem-se os CBH do Rio Doce, nos Estados de Minas Gerais e Espírito Santo; do Rio Paraíba do Sul, nos Estados de São Paulo, Rio de Janeiro e Minas Gerais; dos Rios Piracicaba, Capivari e Jundiaí - PCJ, e do Rio Grande, ambos nos Estados de Minas Gerais e São Paulo.

O Comitê da Bacia do Rio São Francisco, representando a bacia do mesmo nome, também merece destaque dada a participação de mais de 400 municípios, abrangendo os Estados da Bahia, Minas Gerais, Pernambuco, Alagoas, Sergipe e Goiás, além do Distrito Federal.

Por outro lado, as Bacias Amazônica e Atlântico Nordeste Ocidental possuem as menores representações de municípios participantes de $\mathrm{CBH}(23,4 \%$ e 27,2\%, respectivamente) (Tabela 6).

Tabela 6 - Municípios, total e com participação em Comitês de Bacias Hidrográficas, segundo as Regiões Hidrográficas - Brasil - 2013

\begin{tabular}{|c|c|c|c|}
\hline \multirow{3}{*}{ Regiões Hidrográficas } & \multicolumn{3}{|c|}{ Municípios } \\
\hline & \multirow{2}{*}{ Total } & \multicolumn{2}{|c|}{ Com participação em Comitês de Bacias Hidrográficas } \\
\hline & & Total & Percentual (\%) \\
\hline Total & 5563 & 4074 & 73,2 \\
\hline Amazônica & 274 & 64 & 23,4 \\
\hline Tocantins- Araguaia & 383 & 168 & 43,9 \\
\hline Nordeste Ocidental & 195 & 53 & 27,2 \\
\hline Parnaíba & 262 & 111 & 42,4 \\
\hline Nordeste Oriental & 740 & 514 & 69,5 \\
\hline São Francisco & 453 & 397 & 87,6 \\
\hline Atlântico Leste & 490 & 407 & 83,1 \\
\hline Atlântico Sudeste & 509 & 459 & 90,2 \\
\hline Paraná & 1398 & 1233 & 88,2 \\
\hline Atlântico Sul & 427 & 323 & 75,6 \\
\hline Uruguai & 355 & 295 & 83,1 \\
\hline Paraguai & 77 & 50 & 64,9 \\
\hline
\end{tabular}

Fontes: 1. IBGE, Pesquisa de Informações Básicas Municipais 2013. 2. Agência Nacional de Águas - ANA. 
Mapa 3 - Municípios com participação em Comitê de Bacia Hidrográfica - 2013

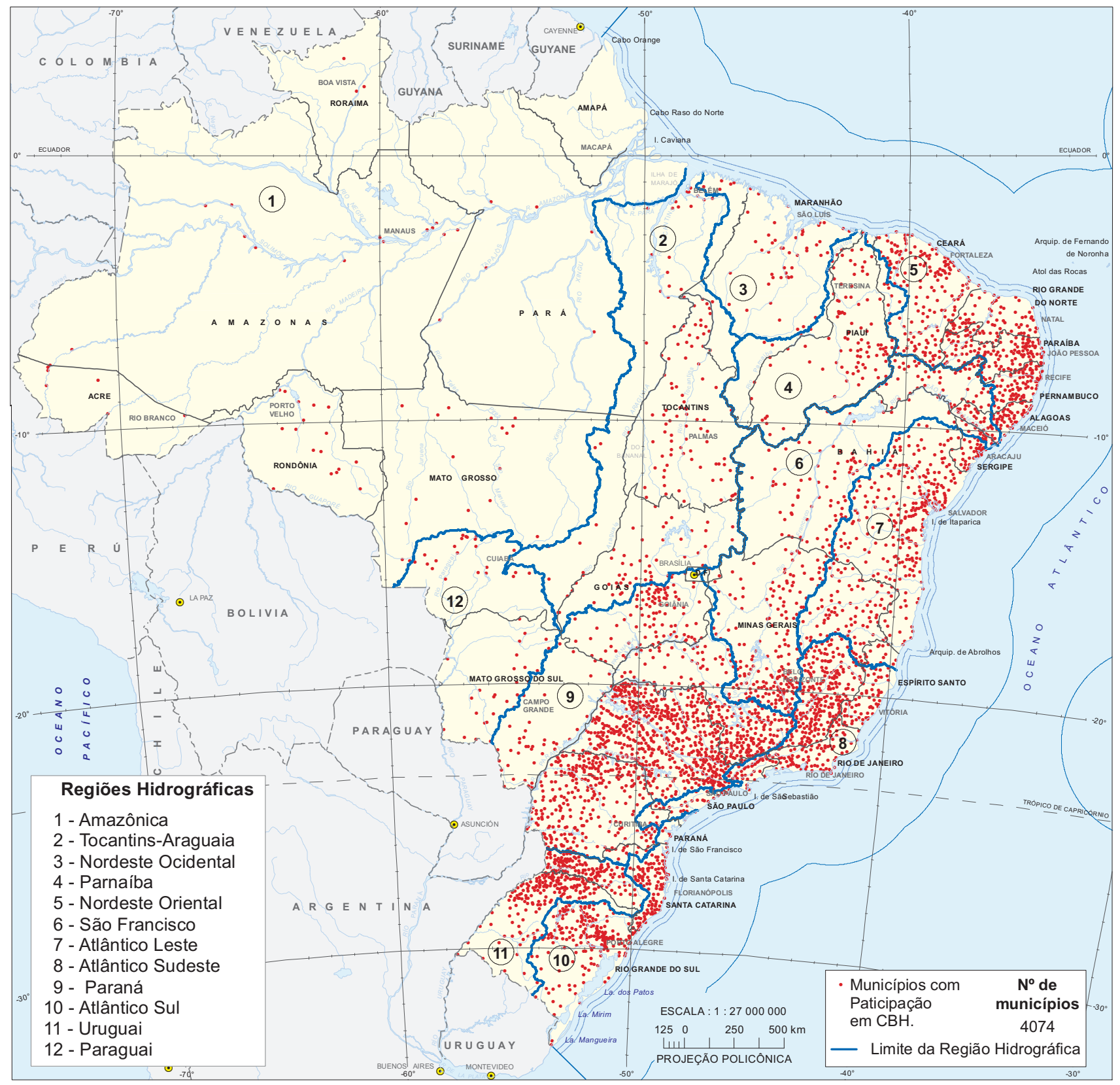

Fontes: 1. IBGE, Pesquisa de Informações Básicas Municipais 2013. 2. Agência Nacional de Águas - ANA. 


\section{Fórum da Agenda 21 Local}

A Agenda 21 Local constitui uma estratégia de apoio ao desenvolvimento contínuo participativo e multissetorial, que trata de questões ambientais, sociais, econômicas, políticas, institucionais e culturais, tendo como base alguns princípios básicos: formação de parcerias, participação social e responsabilidade compartilhada entre governo e sociedade. Portanto, acompanhar a sua expansão geográfica pelo País, o seu avanço ou retrocesso, se reveste de grande relevância enquanto medida do avanço de instrumentos da governança no território brasileiro.

Em 2002, 29,7\% dos municípios brasileiros haviam iniciado a construção da Agenda 21 Local que, em números absolutos, correspondia a 1652 municípios. A proporção era maior (cerca de 69,7\%) entre os mais populosos (acima de 500000 habitantes), fazendo com que metade da população brasileira residisse em municípios com Agenda 21 Local iniciada, segundo o Suplemento de Meio Ambiente da MUNIC 2002 (PERFIL..., 2005). Segundo a Munic 2009, esse percentual alcançou apenas 19,9\%, permanecendo a concentração (60,0\%) das Agendas em municípios mais populosos. Ocorreu uma queda do percentual na Região Nordeste (63,8\%, em 2002, para 25,8\%, em 2009) (PERFIL..., 2010). Isto revela a importância de se construir arranjos institucionais formando uma vasta rede de parcerias, com a participação de governos, organizações da sociedade civil e empresas, além do protagonismo local, para que as iniciativas sejam bem-sucedidas, assegurando a sustentabilidade do processo de desenvolvimento local.

Em 2012, a proporção de municípios com Agenda 21 iniciada alcançou 18,1\%, sendo que entre estes, 57,9\% possuíam mais de 500000 habitantes, proporção menor do que em 2002, conforme a MUNIC 2012 (PERFIL..., 2013). Em 2013, 21,5\% dos municípios (1 197, em números absolutos) haviam iniciado a elaboração das Agendas, sendo que destes, 25,9\% eram municípios entre 20001 e 50000 habitantes e 22,0\% tinham entre 10001 e 20000 habitantes (PERFIL..., 2014).

Os Fóruns da Agenda 21 Local são institucionalidades compostas por representantes do poder público e da sociedade civil, com a missão de elaborar, monitorar e avaliar o Plano Local de Desenvolvimento Sustentável. Uma das suas principais atribuições é representar os anseios dos participantes durante o processo de formulação de políticas e de elaboração e implementação do Plano, definindo uma visão de futuro desejado pela comunidade, que se traduza em ações a serem incluídas no planejamento municipal.

Em 2002, os Fóruns da Agenda 21 Local estavam presentes em 15,0\% dos municípios brasileiros, representando 47,0\% dos que possuíam Agenda 21. Em 2009, a proporção alcançou 11,0\%, representando 63,0\% dos que possuíam Agenda 21. Em 2013, cerca de 13,8\% dos municípios brasileiros possuíam Fórum da Agenda 21 Local, o que representava 64,2\% dos municípios com Agenda 21. Apenas 5,1\% do total dos municípios brasileiros possuíam Fórum ativo (282), ou seja, que se reuniu nos últimos 12 meses à data da pesquisa.

No seu conjunto representavam 23,6\% dos municípios com Agenda 21 iniciada. A distribuição segundo a etapa da Agenda 21 era a seguinte: 110 municípios estavam na etapa de sensibilização/mobilização (39,0\%); 35 estavam definindo o diagnóstico e metodologia (12,4\%); 56 estavam elaborando o Plano Local de Desenvolvimento Sustentável $(19,9 \%)$ e 81 estavam na fase de implementação das ações da Agenda em políticas públicas (28,7\%) (Mapa 4). 
Mapa 4 - Municípios com Fórum da Agenda 21 Local, segundo o estágio da Agenda - 2013

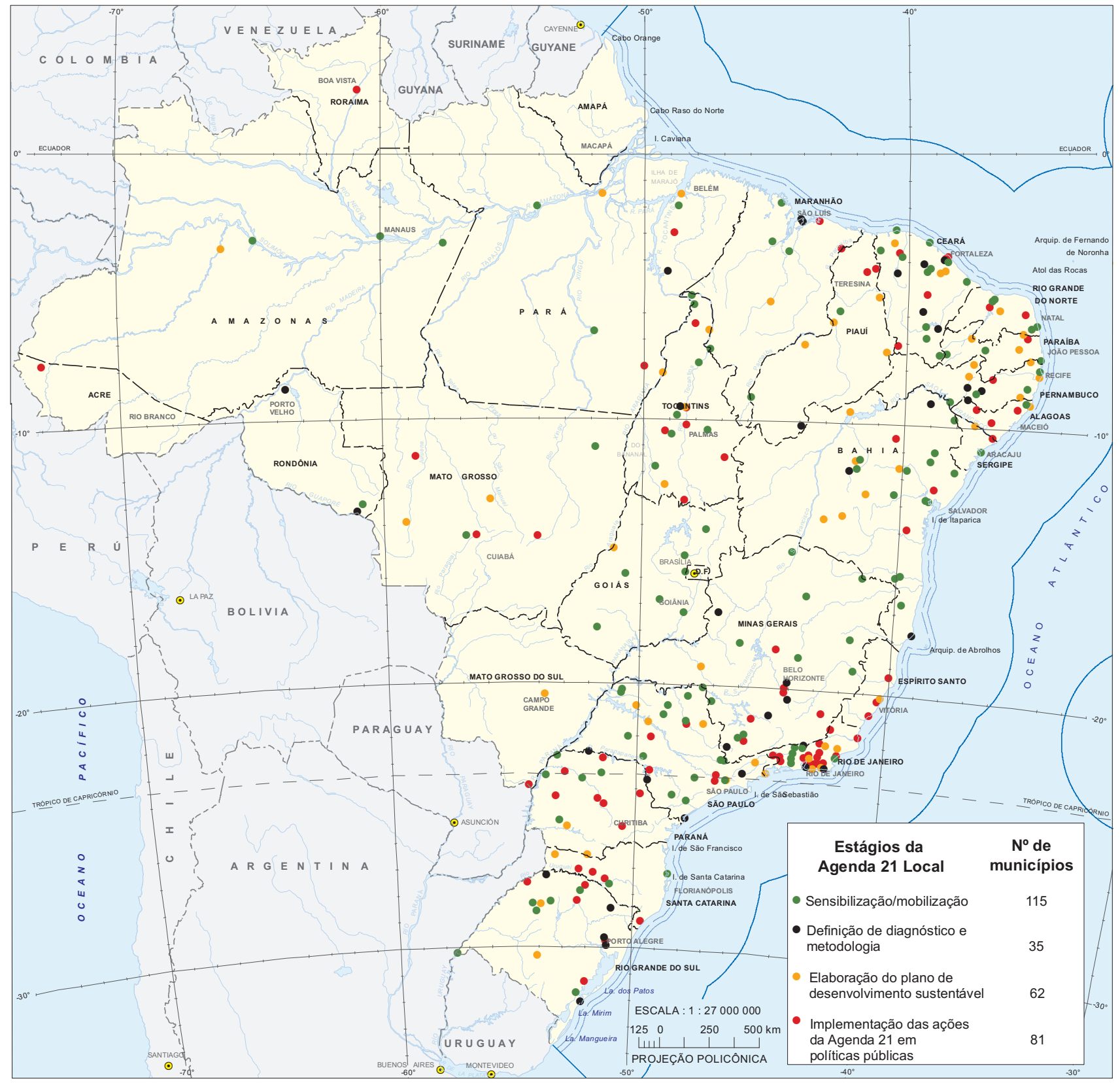

Fonte: IBGE, Pesquisa de Informações Básicas Municipais 2013. 


\section{Articulações interinstitucionais e parcerias na área de meio ambiente}

\section{Consórcios públicos e parcerias com o setor privado}

As dinâmicas locais não podem estar isoladas, sendo necessário articular estratégias municipais com as regionais, nacionais ou até internacionais, a médio e longo prazos, para que as experiências locais possam evoluir a partir das conexões externas virtuosas. A articulação entre os locais pode ser facilitada pela criação de novas formas de gestão, mais flexíveis, ou novas institucionalidades responsáveis por uma gestão intermunicipal voltada para o desenvolvimento regional, como os consórcios de municípios, os $\mathrm{CBH}$, os Conselhos Regionais, os pactos e agências regionais (DOWBOR, 2008). Elas representam "organizações intermediárias entre o Estado, o mercado e a sociedade, que vão instrumentalizar as estratégias de desenvolvimento local" (ALBUQUERQUE; ZAPATA, 2010, p. 224), facilitam a realização de projetos comuns e a resolução de problemas.

As formas de associação na área de meio ambiente, consideradas neste trabalho, foram: consórcios públicos e administrativos entre os entes federativos, convênios de parceria com o setor privado, apoio do setor privado ou de comunidades, programas na área ambiental desenvolvidos em parceria com o governo federal, participação do município na Comissão Interinstitucional de Educação Ambiental - CIEA, participação do município nos Governos Locais pela Sustentabilidade (Local Governments for Susteinability - ICLEI). ${ }^{6}$

Os consórcios públicos são definidos como:

parcerias formadas por dois ou mais entes da federação, para a realização de objetivos de interesse comum em qualquer área, voltados para o desenvolvimento regional. Os consórcios podem ser firmados entre todas as esferas de governo (municípios-municípios, municípios-estados, municípiosestado-União). Entretanto, a União somente participará de consórcios públicos em que também façam parte todos os estados em cujos territórios estejam situados os municípios consorciados. Todo consórcio público possui CNPJ (BRASIL, 2005 apud PESQUISA..., 2011, p. 14).

Sobre os consórcios públicos, Senra declara:

O consórcio público é um instrumento que visa fortalecer a cooperação federativa e dá consistência legal ao arranjo institucional de caráter público para as parcerias entre município, estado, Distrito Federal e União. Os consórcios públicos poderão apoiar a execução de políticas com conteúdos transversais e multidisciplinares. Esta importância se destaca especialmente nas regiões metropolitanas, aglomerações urbanas, bacias hidrográficas, Rides, mesorregiões e microrregiões geográficas onde os grandes problemas urbanos e regionais dependem de gestão compartilhada (SENRA, 2010, p. 62).

\footnotetext{
6 Fundada em 1990 como a International Council for Local Environmental Initiatives - ICLEI.
} 
Os consórcios administrativos são firmados visando interesses comuns nas esferas de governo:

são convênios formados por dois ou mais entes da federação, para a realização de objetivos de interesse comum em qualquer área, voltados para o desenvolvimento regional. Podem ser firmados entre todas as esferas de governo (municípios-municípios, municípios-estados, municípios-estado-União). Entretanto, a União somente participará de consórcios administrativos em que também façam parte todos os estados em cujos territórios estejam situados os municípios consorciados (BRASIL, 2005 apud PESQUISA..., 2011, p. 14).

Convênio de parceria com o setor privado é o "acordo firmado entre o município e o setor privado que assumem e pactuam responsabilidades de projetos e/ou serviços". Apoio do setor privado ou de comunidades "são as ações que contribuem para a realização de algum projeto ou manutenção de serviços em que não seja obrigatória a contrapartida da prefeitura" (BRASIL, 2005 apud PESQUISA..., 2011, p. 15).

Em 2009, era baixo o nível de articulação interinstitucional para tratar de questões ambientais com outros municípios e outras esferas de governo e/ou com o setor privado, conforme apresentado na Tabela 7. Apenas $17,5 \%$ dos municípios realizavam consórcio intermunicipal, proporção que reduziu em 2011 (14,9\%). Para os demais níveis de governo e o setor privado os percentuais eram inferiores a 10,0\% em 2009. Em 2011, as proporções de municípios que realizavam consórcios com o estado e com o governo federal aumentaram em relação a 2009, sendo que apenas 5,6\% dos municípios realizavam consórcio com o governo federal na área de meio ambiente enquanto em 2009 esta proporção era de 2,9\%.

Tabela 7 - Municípios com Articulação Interinstitucional na Política de Meio Ambiente, segundo o tipo de ariticulação interinstitucional - Brasil - 2009/2011

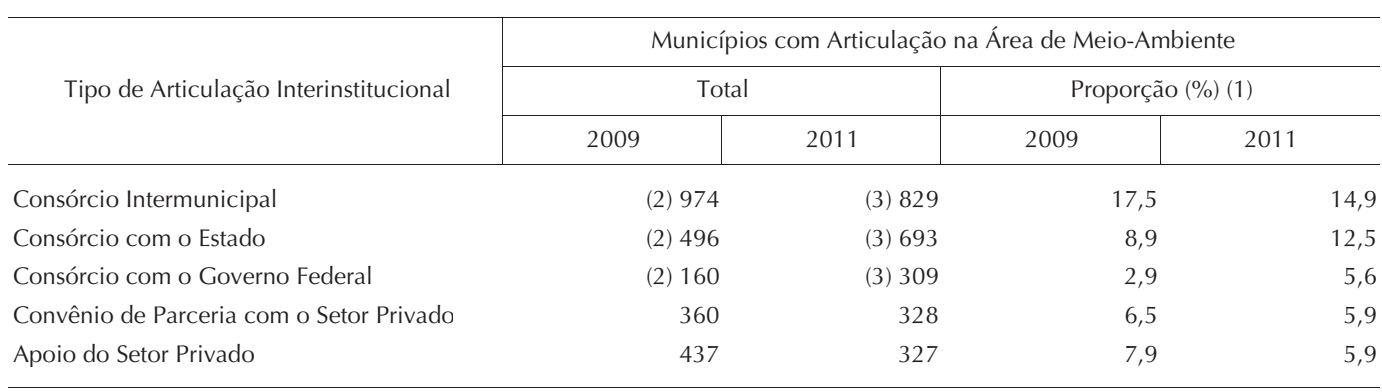

Fonte: IBGE, Pesquisa de Informações Básicas Municipais 2009/2011.

(1) Proporção em relação ao número total de municípios brasileiros. (2) Consórcio público. (3) Para permitir a comparação com o ano de 2009 foram considerados conjuntamente os consórcios públicos e administrativos.

Em termos absolutos, o consórcio público intermunicipal era o tipo de articulação que predominava em 2011, praticado em 704 municípios, seguido do consórcio administrativo com o estado (431 municípios) e do convênio de parceria com o setor privado (328 municípios) (Mapas 5, 6 e 7). 
Mapa 5 - Municípios com articulações interinstitucionais: consórcio público - 2011

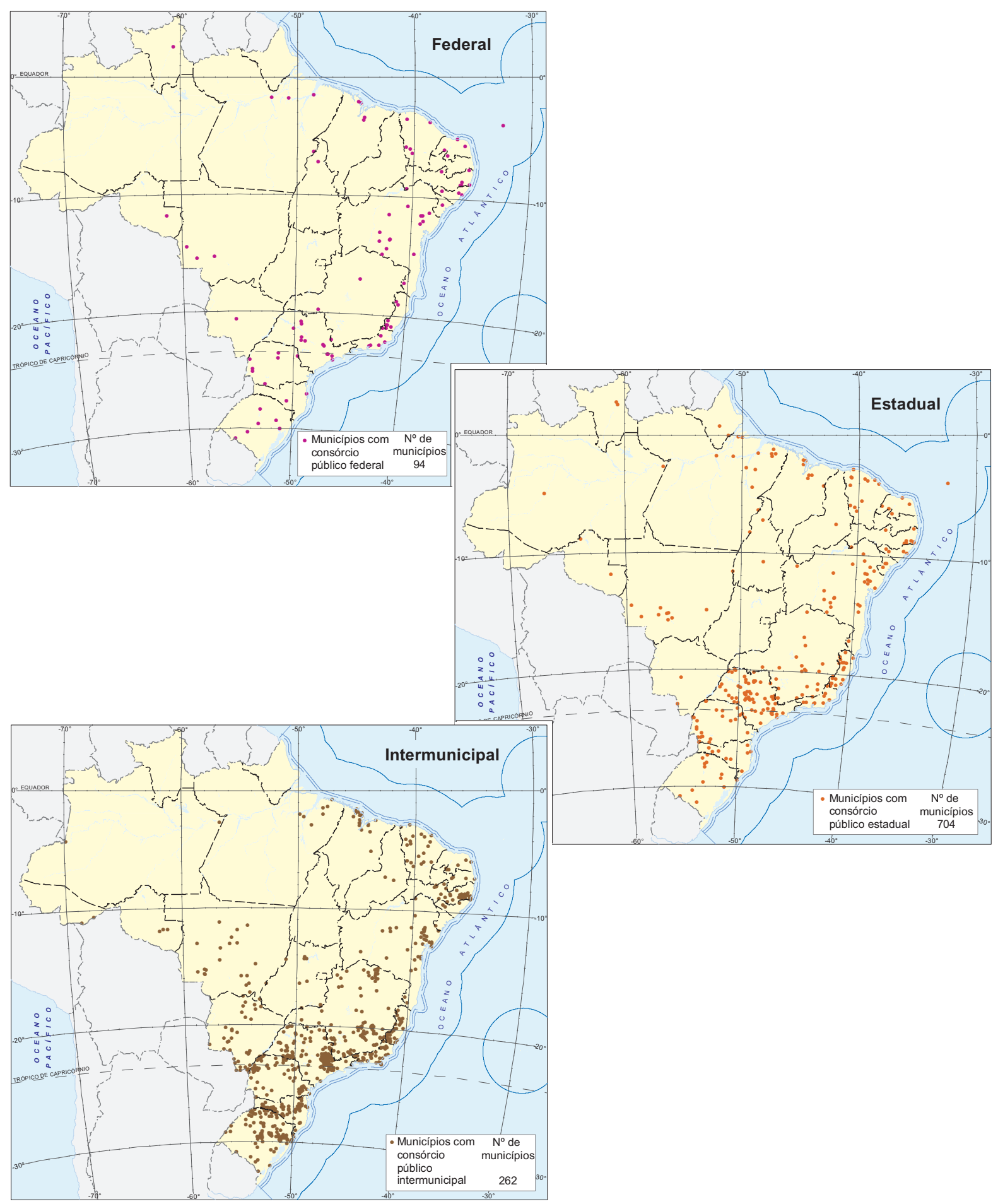

Fonte: IBGE, Pesquisa de Informações Básicas Municipais 2011. 
Mapa 6 - Municípios com articulações interinstitucionais: consórcio administrativo - 2011

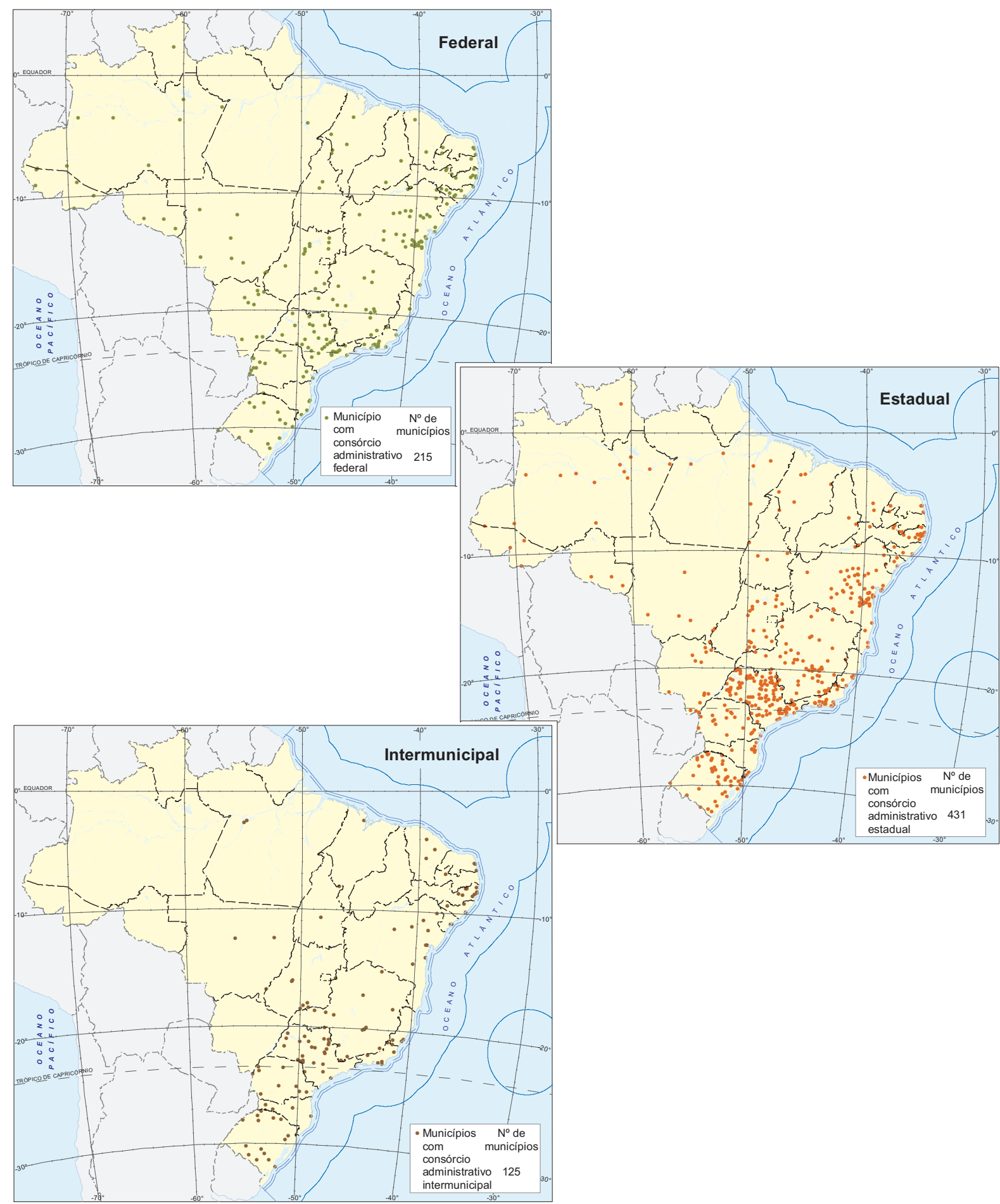

Fonte: IBGE, Pesquisa de Informações Básicas Municipais 2011. 
Mapa 7 - Municípios com articulações interinstitucionais - 2011
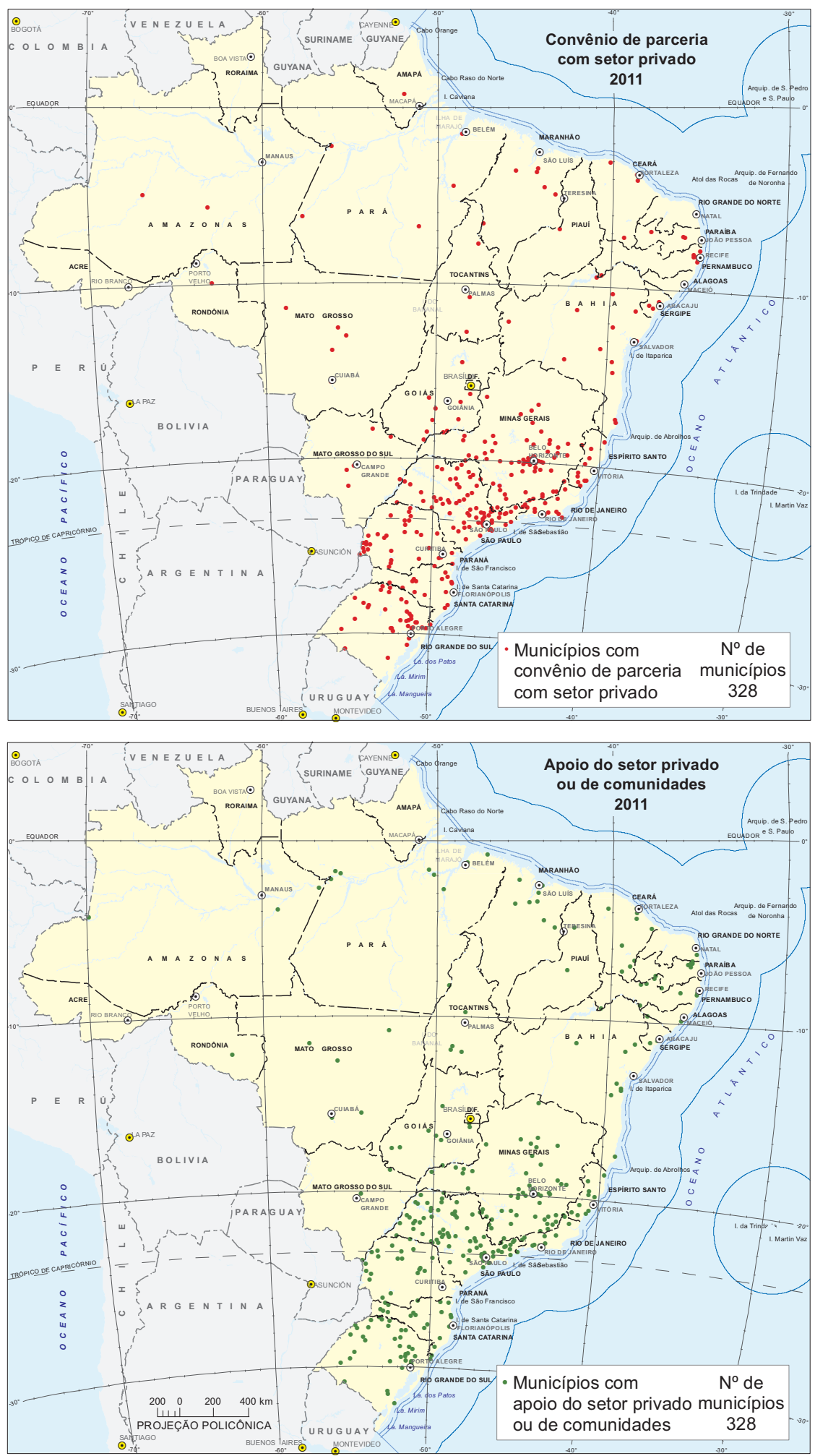

Fonte: IBGE, Pesquisa de Informações Básicas Municipais 2011. 


\section{Outros programas de parcerias}

A MUNIC, do IBGE investigou em 2013 a presença, nos municípios, de um conjunto de programas da área ambiental desenvolvidos em parceria com o governo federal, que estão descritos no Quadro 1.

Quadro 1 - Programas e ações ambientais do governo federal

\begin{tabular}{|c|c|c|}
\hline Programas ambientais & Descrição geral dos Programas & Órgãos responsáveis \\
\hline Coletivo Educador & $\begin{array}{l}\text { Conjuntos de instituições atuantes em processos } \\
\text { formativos permanentes, participativos, } \\
\text { continuados e voltados à totalidade e diversidade } \\
\text { de habitantes de um determinado território. É } \\
\text { resultado e realizador do Programa Nacional de } \\
\text { Educação Ambiental - ProNEA e do Programa } \\
\text { Nacional de Formação de Educadoras e } \\
\text { Educadores Ambientais - ProFEA. }\end{array}$ & Ministério do Meio Ambiente \\
\hline Sala Verde & $\begin{array}{l}\text { É um espaço definido, vinculado a uma } \\
\text { instituição pública ou privada, que poderá se } \\
\text { dedicar a projetos, ações e programas } \\
\text { educacionais voltados à questão ambiental. São } \\
\text { potenciais centros de informação e formação } \\
\text { ambiental. }\end{array}$ & $\begin{array}{l}\text { Departamento de Educação Ambiental do } \\
\text { Ministério do Meio Ambiente }\end{array}$ \\
\hline Circuito Tela Verde - CTV & $\begin{array}{l}\text { Tem o objetivo de atender à demanda por } \\
\text { material audiovisual para tratar a educação } \\
\text { ambiental nos espaços educadores; estimular a } \\
\text { produção audiovisual independente sobre a } \\
\text { temática socioambiental. }\end{array}$ & $\begin{array}{l}\text { Departamento de Educação Ambiental - } \\
\text { DEA e Secretaria de Articulação } \\
\text { Institucional e Cidadania Ambiental - } \\
\text { SAIC do Ministério do Meio Ambiente em } \\
\text { parceira com a Secretaria do Audiovisual - } \\
\text { SAv do Ministério da Cultura. }\end{array}$ \\
\hline $\begin{array}{l}\text { Conferência Nacional } \\
\text { Infantojuvenil pelo Meio } \\
\text { Ambiente - CNIJMA }\end{array}$ & $\begin{array}{l}\text { Campanha pedagógica que traz a dimensão da } \\
\text { política ambiental para a educação que mobiliza } \\
\text { jovens entre } 11 \text { e } 14 \text { anos em pesquisas e debates } \\
\text { com a comunidade escolar sobre os desafios } \\
\text { socioambientais contemporâneos. }\end{array}$ & $\begin{array}{l}\text { Diretoria de Educação Ambiental - DEA } \\
\text { do Ministério do Meio Ambiente } \\
\text { Coordenação Geral de Educação } \\
\text { Ambiental - CGEA do Ministério da } \\
\text { Educação }\end{array}$ \\
\hline $\begin{array}{l}\text { Educação Ambiental no Plano } \\
\text { de Gestão Integrada de Resíduos } \\
\text { Sólidos -PGIRS }\end{array}$ & $\begin{array}{l}\text { Programas e ações de educação ambiental devem } \\
\text { fazer parte do PGIRS conforme proposta } \\
\text { metodológica contida no manual de orientação } \\
\text { do plano. }\end{array}$ & Ministério do Meio Ambiente \\
\hline $\begin{array}{l}\text { Agenda Ambiental na } \\
\text { Administração Pública - A3P }\end{array}$ & $\begin{array}{l}\text { Tem o objetivo de implementar a gestão } \\
\text { socioambiental sustentável das atividades } \\
\text { administrativas e operacionais do governo. Seus } \\
\text { princípios vão desde uma mudança dos } \\
\text { investimentos, compras e contratação de serviços } \\
\text { pelo governo até uma gestão adequada dos } \\
\text { resíduos gerados e dos recursos naturais } \\
\text { utilizados visando a melhoria da qualidade de } \\
\text { vida no ambiente de trabalho. }\end{array}$ & Ministério do Meio Ambiente \\
\hline
\end{tabular}

Fontes: 1. IBGE, Pesquisa de Informações Básicas Municipais 2013. 2. Ministério do Meio Ambiente. Ver referências. 
No que se refere à participação dos municípios nestes programas da área ambiental, 34,1\% (1 902) dos municípios brasileiros implantaram pelo menos um dos programas investigados, segundo a MUNIC, realizada pelo IBGE em 2013 (PERFIL..., 2014). Ainda segundo a MUNIC 2013,

o programa de maior incidência $(25,5 \%)$ é o de Educação Ambiental no Plano de Gestão Integrada de Resíduos Sólidos, por ser este último uma exigência prevista na legislação da Política Nacional de Resíduos Sólidos. A elaboração desse plano é condição para o município ter acesso a recursos, incentivos e financiamentos do governo federal disponíveis para essa área (PERFIL..., 2014, p. 73).

Os demais programas têm a seguinte participação percentual, em relação ao total de municípios brasileiros: Conferência Infantojuvenil pelo Meio Ambiente (9,0\%), Sala Verde $(6,5 \%)$, Sustentabilidade ambiental das instituições públicas como a Agenda Ambiental na Administração Pública (5,2\%), Coletivo Educador (4,4\%) e Circuito Tela Verde (1,7\%) (Mapa 8).

Em 2013, somente 6,4\% dos municípios brasileiros participavam da Comissão Interinstitucional de Educação Ambiental - CIEA, com pelo menos uma reunião realizada nos últimos 12 meses (Mapa 9).

A CIEA tem como finalidade,

promover a discussão, a gestão, a coordenação, o acompanhamento e a avaliação, bem como a implementação das atividades em educação ambiental. A Comissão pode ser de âmbito estadual ou similar, podendo ser de caráter consultivo e/ou deliberativo (PERFIL..., 2014, p. 74).

A Munic pesquisou, em 2012, a participação do município em alguma rede internacional de cidades. Entre os temas tratados no questionário da pesquisa, selecionamos a rede ICLEl, que é uma "associação democrática e internacional de governos locais e organizações governamentais nacionais e regionais que assumiram um compromisso com o desenvolvimento sustentável" (PERFIL..., 2013, anexo). Cabe observar que apenas 19 municípios participavam desta rede no ano considerado: Aveiro, Fortaleza, Belo Horizonte, Contagem, Vitória, Rio de Janeiro, Campinas, Cananéia, Guarulhos, Mauá, Osasco, Santo André, São Carlos, São Paulo, Guaratuba, Toledo, Porto Alegre, Santa Maria e Goiânia. 
Mapa 8 - Parceria de governo municipal com o governo federal para implementação de programas de meio ambiente, por tipo de programa - 2013
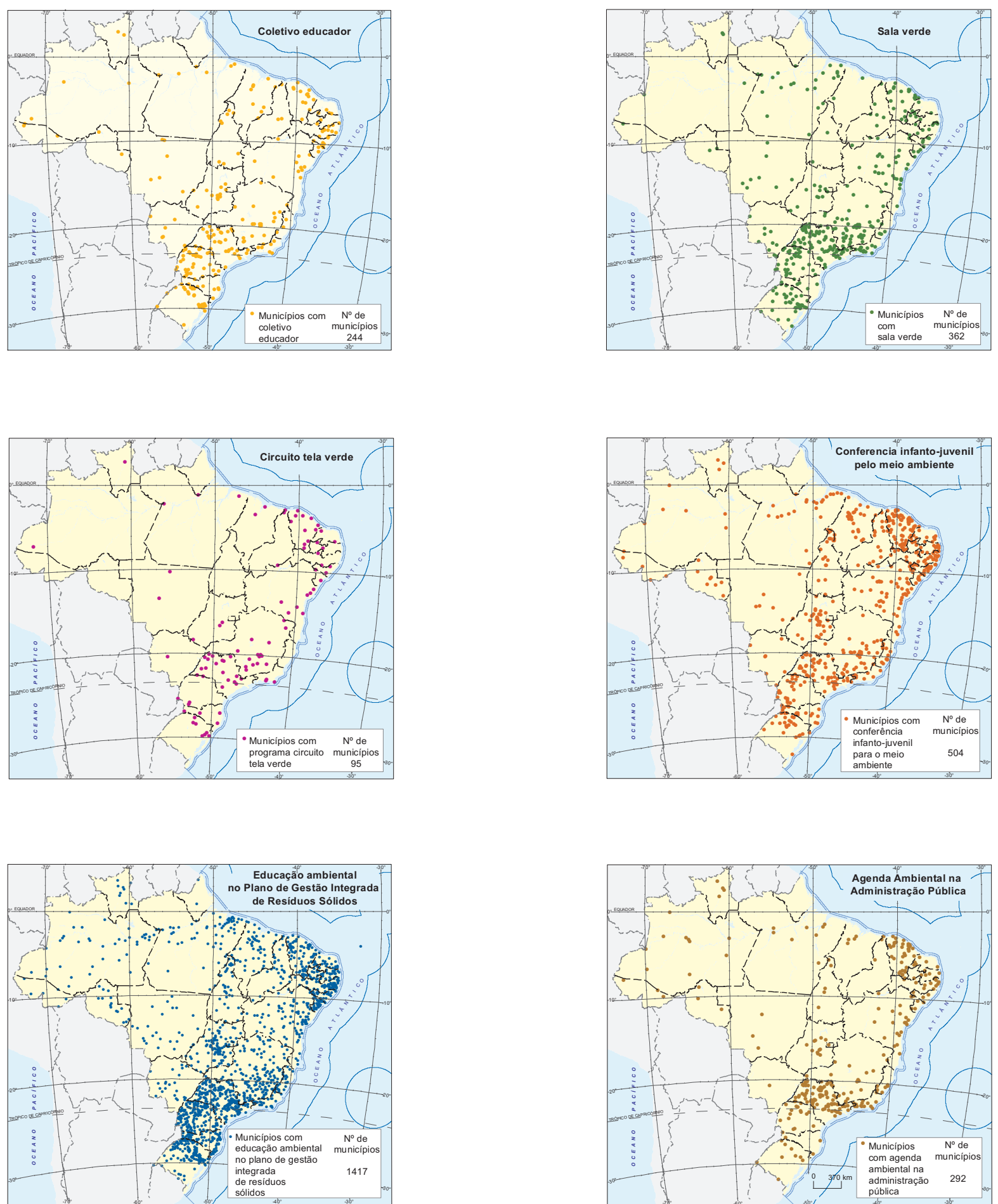

Fonte: IBGE, Pesquisa de Informações Básicas Municipais 2013. 
Mapa 9 - Comissão Interinstitucional de Educação Ambiental - CIEA de âmbito estadual ou similar - 2013

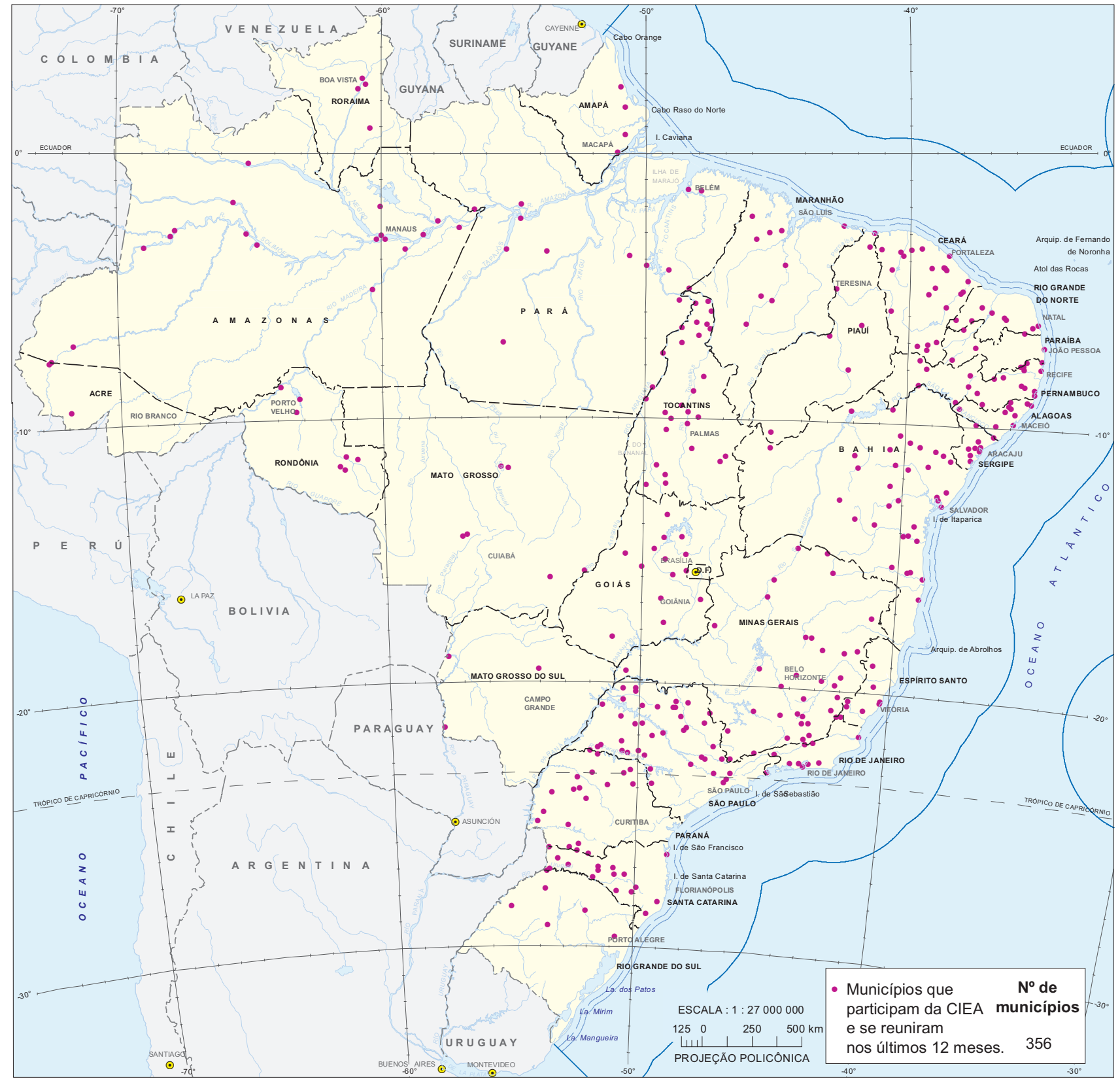

Fonte: IBGE, Pesquisa de Informações Básicas Municipais 2013. 


\section{Considerações finais}

As institucionalidades participativas correspondentes aos Conselhos de Meio Ambiente, Comitês de Bacias Hidrográficas e Fórum da Agenda 21 Local, consideradas neste capítulo, apresentaram algumas semelhanças quanto à frequência de ocorrência nos municípios e, portanto, em sua distribuição geográfica no território brasileiro.

Os Conselhos tiveram representação em 3784 municípios $(67,9)$, sendo ativos em 2873 (51,5). A participação em Comitês de bacias foi a mais representativa, ocorrendo em 4074 municípios brasileiros (73,0\%); enquanto a participação no Fórum da Agenda 21 Local foi a menos representativa, com a ocorrência em 1197 municípios brasileiros (21,5\%). Nos três casos houve maior participação nas Regiões Sudeste e Sul e em municípios com população superior a 500000 habitantes. No entanto, apenas 212 municípios possuem, simultaneamente, Conselho de Meio Ambiente ativo, Comitê de Bacia e Fórum ativo da Agenda 21 Local (Mapas 2, 3 e 4), revelando, a princípio, uma maior participação e poder de articulação e intervenção nas questões que envolvem a gestão ambiental e o desenvolvimento local. No entanto, conforme comentado anteriormente, a quantificação em si não nos permite garantir a qualidade e efetiva participação da sociedade civil nestes organismos e os resultados efetivos no espaço local. Outros elementos seriam necessários para mensuração de tais efeitos nos municípios brasileiros.

Em termos de articulações e parcerias, cerca de 29,1\% dos municípios brasileiros efetuam algum tipo de articulação interinstitucional, seja com outro ente federativo ou com o setor privado. Destes, 87,5\% realizam de 1 a 2 tipos de articulação (1 418 municípios); 10,4\% realizam de 3 a 4 tipos de articulação (168 municípios); e 2,1\% realizam de 5 a 7 tipos (34 municípios) (Mapa 10). Aproximadamente 108 municípios têm convênio de parceria com o setor privado e também recebem apoio do setor privado, 42 municípios têm os três tipos de consórcio público (intermunicipal, estadual e federal) e 19 municípios têm consórcio administrativo simultaneamente nos três níveis (intermunicipal, estadual e federal).

Aproximadamente 34,0\% dos municípios brasileiros tem algum programa de meio ambiente praticado em parceria com o governo federal, o que representa 1902 municípios. Destes, 87,1\% (1 657 municípios) têm 1 ou 2 programas implementados, 11,3\% (214) têm 3 ou 4 programas e somente 1,6\% (31) tem 5 ou 6 (Mapa 10). Os municípios que têm simultaneamente os seis programas mencionados neste trabalho são: Buriti dos Lopes, Fortaleza, Juazeiro do Norte, Quixeramobim, Severínia, Suzanópolis e Itaguajé.

As diferentes práticas de governança aqui consideradas cruzam-se, por diversas vias, na temática do desenvolvimento local. Múltiplas escalas estão presentes, no sentido de que foram consideradas formas de articulação entre diferentes níveis de governo (município-município, município-estado, município-União), entre governo municipal e iniciativa privada, nas diversas esferas públicas (Conselhos, Comitês, Fóruns) e nos vínculos internacionais, como o ICleı. Vale ressaltar que a existência destas formas de governança, sobretudo quando ocorrem simultaneamente num mesmo território, pode indicar alterações no modo de perceber e construir o desenvolvimento. No entanto, é necessário avaliar se a participação da sociedade é efetiva, ou seja, se a gestão é de fato compartilhada e como estas formas nutrem as experiências de desenvolvimento local. 
Mapa 10 - Municípios com articulações interinstitucionais e parcerias na área de meio ambiente - $2011 / 2013$
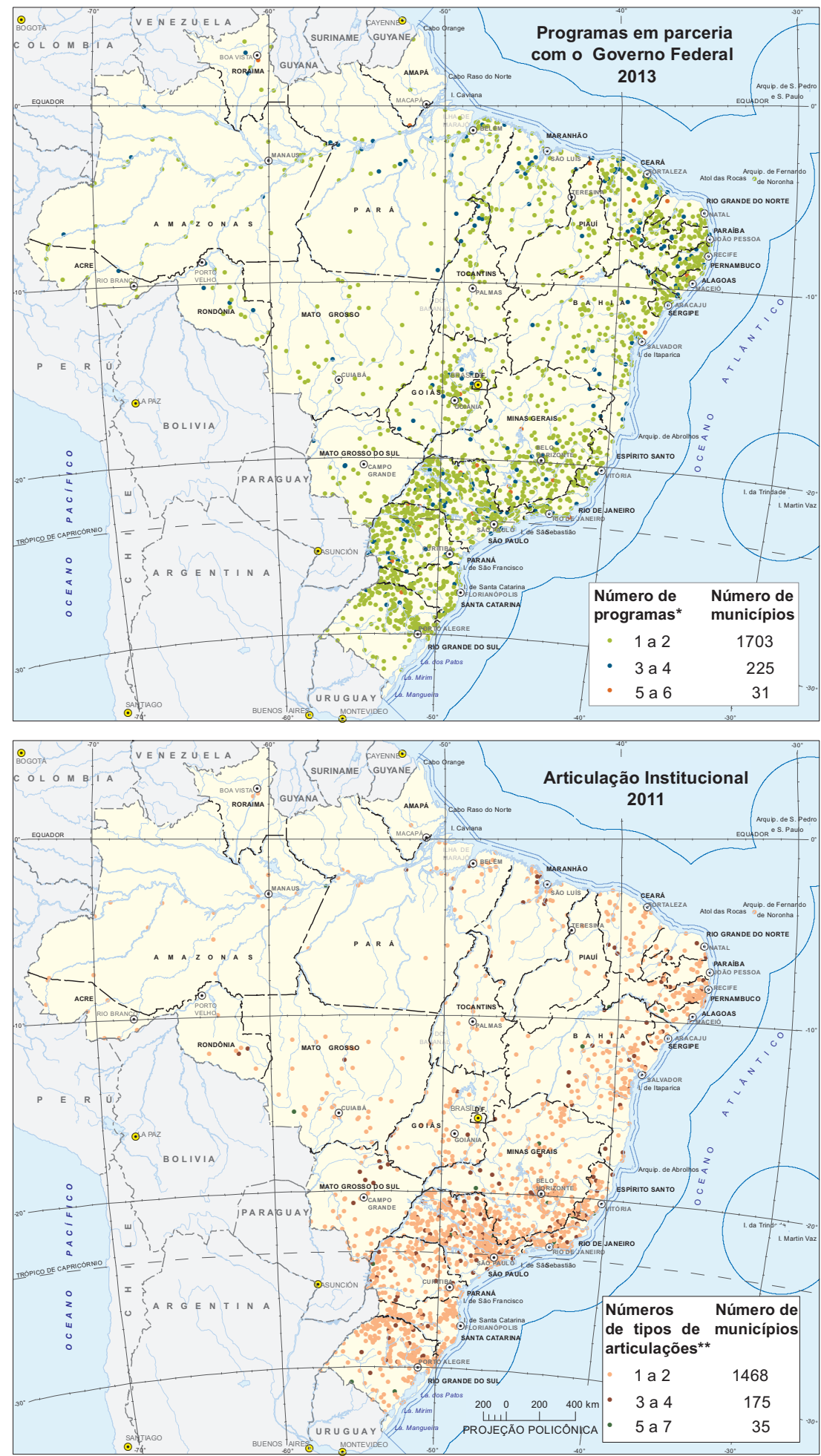

Fonte: IBGE, Pesquisa de Informações Básicas Municipais 2011/2013. 


\section{Referências}

ALBAGLI, S. Sociedade da informação e do conhecimento: novos desafios às políticas de informação em ciência, tecnologia e inovação. In: CONGRESSO BRASILEIRO DE SOCIOLOGIA, 13., 2007, Recife. Anais... Recife: Universidade Federal de Pernambuco - UFPE, 2007. Disponível em: <http://www.sbsociologia.com.br/portal/index. php?option=com_docman>. Acesso em: jun. 2016.

Território e territorialidade. In: BRAGA, C.; MORELLI, G.; LAGES, V. N. (Org.). Territórios em movimento: cultura e identidade como estratégia de inserção competitiva. Rio de Janeiro: Relume Dumará; Brasília, DF: Serviço de Apoio às Micro e Pequenas Empresas - Sebrae, 2004. Apresentação Ignacy Sachs. p. 25-69. Disponível em: <http://inspirebr.com. br/uploads/midiateca/d64c55dfd943251ede2b6330035a5994.pdf>. Acesso em: jun. 2016.

ALBAGLI, S.; BRITTO, J. (Org). Glossário de arranjos e sistemas produtivos e inovativos locais: relatório da fase piloto. Rio de Janeiro: Universidade Federal do Rio de Janeiro UFRJ, Instituto de Economia, 2002. Estudo da Rede de Pesquisa em Sistemas Produtivos e Inovativos Locais - RedSist. Disponível em: <http://www.ie.ufrj.br/redesist/Glossario/ Glossario\%20Sebrae.pdf>. Acesso em: jun. 2016.

ALBUQUERQUE, F.; ZAPATA, T. A importância da estratégia de desenvolvimento local/territorial no Brasil. In: DOWBOR, L., POCHMANN, M. (Org.). Políticas para o desenvolvimento local. São Paulo: Fundação Perseu Abramo - FPA, 2010. p. 215-229. Disponível em: <http://dowbor.org/blog/wp-content/uploads/2012/06/10PochmannLivroLo calPoliticas-1.pdf $>$. Acesso em: jun. 2016.

ALCOFORADO, F. Globalização e desenvolvimento. São Paulo: Nobel, 2006. 213 p.

BACIAS hidrográficas. Brasília, DF: Agência Nacional de Águas - ANA. Disponível em: <http://www2.ana.gov.br/Paginas/portais/bacias/default.aspx>. Acesso em: jun. 2016.

BRASIL. Constituição (1988). Constituição da República Federativa do Brasil. Brasília, DF, [2016a]. Disponível em: <http://www.presidencia.gov.br/legislacao> Acesso em: jun. 2016.

Lei n. 11.107, de 6 de abril de 2005. Dispõe sobre normas gerais de contratação de consórcios públicos e dá outras providências. In: PESQUISA de informações básicas municipais: manual de coleta: 2011. [Rio de Janeiro]: IBGE, 2011. Disponível em: <http:// biblioteca.ibge.gov.br/index.php/biblioteca-catalogo?view=detalhes\&id=52632>. Acesso em: jun. 2016.

Ministério do Meio Ambiente. Agenda ambiental na administração pública: A3P. Brasília, DF, 2016b. Disponível em: <http://www.mma.gov.br/destaques/item/8852>. Acesso em: jun. 2016.

Ministério do Meio Ambiente. Circuito tela verde. Brasília, DF, 2016c. Disponível em: <http://www.mma.gov.br/educacao-ambiental/educomunicacao/circuito-tela-verde>. Acesso em: jun. 2016. 
Ministério do Meio Ambiente. Coletivos educadores. Brasília, DF, 2016d. Disponível em: $\quad<$ http://www.mma.gov.br/educacao-ambiental/formacao/pronatec/item/363forma\%C3\%A7\%C3\%A3o-de-educadores-coletivos-educadores $>$. Acesso em: jun. 2016.

. Ministério do Meio Ambiente. Conferência Nacional Infantojuvenil pelo Meio Ambiente. Brasília, DF, 2016e. Disponível em: <http://conferenciainfanto.mec.gov.br/>. Acesso em: jun. 2016.

Ministério do Meio Ambiente. Planos de gestão de resíduos sólidos: manual de orientação: apoiando a implementação da política nacional de resíduos sólidos: do nacional ao local. Brasília, DF, 2016f. Disponível em: <http://www.mma.gov.br/estruturas/182/_ arquivos/manual_de_residuos_solidos3003_182.pdf>. Acesso em: jun. 2016.

Ministério do Meio Ambiente. Salas verdes. Brasília, DF, 2016g. Disponível em: $<$ http://www.mma.gov.br/educacao-ambiental/educomunicacao/salas-verdes $>$. Acesso em: jun. 2016.

BUARQUE, S. C. Construindo o desenvolvimento local sustentável: metodologia de planejamento. Rio de Janeiro: Garamond, 2002. 177 p. (Terra mater).

COMITÊS de Bacias Hidrográficas. Brasília, DF, 2014. Disponível em: <http://www.cbh.gov. br/>. Acesso em: jun. 2016.

CONJUNTO de normas legais: recursos hídricos. 7 ed. Brasília, DF: Conselho Nacional de Recursos Hídricos - CNRH. 2011.

CONJUNTURA dos recursos hídricos no Brasil 2013. Brasília, DF: Agência Nacional de Águas - ANA, 2013. Disponível em: <http://arquivos.ana.gov.br/institucional/spr/conjuntura/ webSite_relatorioConjuntura/projeto/index.html>. Acesso em: jun. 2016.

CONSELHO NACIONAL DE RECURSOS HÍDRICOS (Brasil). Resolução n. 32, de 15 de outubro de 2003. Institui a Divisão Hidrográfica Nacional. Brasília, DF: CNRH, 2003. Disponível em: <http://www.cnrh.gov.br/>. Acesso em: jun. 2016.

CONSELHO NACIONAL DO MEIO AMBIENTE (Brasil). Resolução n. 237, de 19 de dezembro de 1997. Regulamenta os aspectos de licenciamento ambiental estabelecidos na Política Nacional do Meio Ambiente. Brasília, DF: Conama, 1997. Disponível em: <http:// www.mma.gov.br/port/conama/res/res97/res23797.html>. Acesso em: jun. 2016.

CONSELHOS de meio ambiente no Brasil: conselhos estaduais, conselhos municipais. Brasília, DF: Ministério do Meio Ambiente, 2014. Disponível em: <http://www.mma.gov.br/ port/conama/conselhos/conselhos.cfm>. Acesso em: jun. 2016.

D'ARAúJO, M. C. Capital social. Rio de Janeiro: Zahar, 2003. 65 p. (Passo a passo, 25).

DOWBOR, L. Democracia econômica: alternativas de gestão social. Petrópolis: Vozes, 2008. 214 p.

FRANCO. A. de. Desenvolvimento local integrado e sustentável: dez consensos. Proposta: experiências em educação popular. Rio de Janeiro: Federação de Órgãos para Assistência Social e Educacional - FASE, v. 27, n. 78, 1998. 
Pobreza e desenvolvimento local. Brasília, DF: Agência de Educação para o Desenvolvimento - AED, 2002. 294 p.

AS FUNDAÇÕES privadas e associações sem fins lucrativos no Brasil 2010. Rio de Janeiro: IBGE, 2012. 173 p. (Estudos e pesquisas. Informação econômica, n. 20). Acompanha 1 CD-ROM. Estudo realizado pelo IBGE em parceria com o Instituto de Pesquisa Econômica Aplicada - IPEA, a Associação Brasileira de Organizações Não Governamentais - Abong e o Grupo de Institutos, Fundações e Empresas - GIFE. Disponível em: <ftp://ftp.ibge.gov.br/ Fundacoes_Privadas_e_Associacoes/2010/fasfil.pdf>. Acesso em: jun. 2016.

INDICAÇÕES geográficas brasileiras. Brasília, DF: Serviço Brasileiro de Apoio às Micro e Pequenas Empresas - Sebrae; Instituto Nacional da Propriedade Industrial - INPI, 2014. 264 p. Disponível em: <http://www.sebrae.com.br/sites/PortalSebrae/bis/catalogo-indicacoesgeograficas-brasileiras,c1e390411e9e9410VgnVCM2000003c74010aRCRD>. Acesso em: jun. 2016.

INDICADORES de desenvolvimento sustentável: Brasil 2015. Rio de Janeiro: IBGE, 2015. 351 p. Disponível em: <http://biblioteca.ibge.gov.br/index.php/biblioteca-catalogo?view=d etalhes\&id=294255>. Acesso em: jun. 2016.

LEDO, S. O papel dos conselhos municipais de meio ambiente e de desenvolvimento sustentável. [S. I.: s. n.], [2013].

MELO NETO, F. P. de; FRÓES, C. Empreendedorismo social: a transição para a sociedade sustentável. Rio de Janeiro: Qualitymark, 2002. 208 p.

OLIVEIRA, S. M. C. de; BARCELLOS, F. C.; GREEN, A. P. L. Urbanização, impactos ambientais e governança no complexo regional centro-sul. Revista Iberoamericana de Economía Ecológica - Revibec, Morelia: Universidad Nacional Autônoma de México - UNAM, v. 16-17, p. 17-32, 2011. Disponível em: <http://www.redibec.org/revibec.html>. Acesso em: jun. 2016.

PERFIL dos municípios brasileiros 2009. Rio de Janeiro: IBGE, 2010. 477 p. Acompanha 1CD-ROM. Acima do título: Pesquisa de Informações Básicas Municipais. Disponível em: $<$ http://www.ibge.gov.br/home/estatistica/economia/perfilmunic/defaulttab1_perfil.shtm>. Acesso em: jun. 2016.

PERFIL dos municípios brasileiros 2012. Rio de Janeiro: IBGE, 2013. 271 p. Acompanha 1CD-ROM. Acima do título: Pesquisa de Informações Básicas Municipais. Disponível em: $<$ http://www.ibge.gov.br/home/estatistica/economia/perfilmunic/defaulttab1_perfil.shtm>. Acesso em: jun. 2016.

PERFIL dos municípios brasileiros 2013. Rio de Janeiro: IBGE, 2014. 284 p. Acompanha 1CD-ROM. Acima do título: Pesquisa de Informações Básicas Municipais. Disponível em: $<$ http://www.ibge.gov.br/home/estatistica/economia/perfilmunic/defaulttab1_perfil.shtm>. Acesso em: jun. 2016.

PERFIL dos municípios brasileiros: meio ambiente 2002. Rio de Janeiro: IBGE, 2005. Acompanha 1CD-ROM. Acima do título: Pesquisa de Informações Básicas Municipais. Disponível em: <http://www.ibge.gov.br/home/estatistica/economia/perfilmunic/meio_ ambiente_2002/default.shtm>. Acesso em: jun. 2016. 
PAIVA, F.; MONTEIRO, J. de P. Os 5 elementos: a essência da gestão compartilhada no pacto de cooperação do Ceará. Rio de Janeiro: Qualitymark, 2001. 119 p.

PAULA, J. de. Desenvolvimento local: textos selecionados. Brasília, DF: Serviço Brasileiro de Apoio às Micro e Pequenas Empresas - Sebrae, 2008. 79 p.

PECQUEUR, B. O desenvolvimento territorial: uma nova abordagem dos processos de desenvolvimento para as economias do Sul. Raízes, Campina Grande: Universidade Federal de Campina Grande - UFCG, Centro de Humanidades, v. 24, n. 1/2, p. 10-22, jan./dez. 2005. Disponível em: <http://www.ufcg.edu.br/ raizes/>. Acesso em: jun. 2016.

RIO DE JANEIRO (RJ). Rio Lei Orgânica do Município. 2. ed. rev. e ampl. Rio de Janeiro: Procuradoria-Geral do Município - PGM, 2010. 224 p. Texto atualizado até a Emenda n. 20/2009. Disponível em: <http://www.rio.rj.gov.br/web/pgm>. Acesso em: jun. 2016.

SANTOS, M. O espaço do cidadão. 7. ed. São Paulo: Editora da Universidade de São Paulo - Edusp, 2007. 176 p. (Coleção Milton Santos, 8).

SENRA, K. V. Políticas e instituições para desenvolvimento econômico territorial: o caso do Brasil. Santiago do Chile: Comissão Econômica para a América Latina e o Caribe Cepal, 2010. 109 p. (Desarrollo territorial, 8). Disponível em: <http://bibspi.planejamento. gov.br/bitstream/handle/iditem/499/05\%20Desenvolvimento\%20territorial_ILPES. pdf? sequence=1>. Acesso em: jun. 2016.

SILVEIRA, C. M. Desenvolvimento local e novos arranjos socioinstitucionais: algumas referências para a questão da governança. In: DOWBOR, L.; POCHMANN, M. (Org.). Políticas para o desenvolvimento local. São Paulo: Fundação Perseu Abramo - FPA, 2010. 400 p. p. 41 - 65. Disponível em: <http://dowbor.org/blog/wp-content/uploads/2012/06/10P ochmannLivroLocalPoliticas-1.pdf>. Acesso em: jun. 2016.

SINGER, P. Economia solidária: um modo de produção e distribuição. In: SINGER, P.; SOUZA, A. R. (Org.). Economia solidária no Brasil: a autogestão como resposta ao desemprego. 2. ed. São Paulo: Contexto, 2003, 360 p. p. 11-28. (Coleção Economia).

SPERANZA, J. S. Limites e possibilidades do desenvolvimento local. Sinais Sociais, Rio de Janeiro: Serviço Social do Comércio - Sesc, v. 1, n. 2, p. 142-187, set./dez. 2006. Disponível em: <http://www.sesc.com.br/wps/wcm/connect/9e034e9d-479e-4acbbe2f-a78653d3cd07/02.pdf?MOD=AJPERES\&CACHEID=9e034e9d-479e-4acb-be2fa78653d3cd07>. Acesso em: jun. 2006.

TENÓRIO, F. G. Cidadania e desenvolvimento local: critérios de análise. Rio de Janeiro: Fundação Getulio Vargas - FGV, 2012. 264 p. 